\title{
Production Fragmentation and Trade Integration: East Asia in a Global Context
}

\author{
Prema-chandra Athukorala \\ Nobuaki Yamashita \\ Division of Economics \\ Research School of Pacific and Asian Studies \\ The Australian National University
}

\begin{abstract}
This paper examines the implications of international production fragmentation for analysing global and regional trade patterns, with special emphasis on countries in East Asia. It is found that, while 'fragmentation trade' has generally grown faster than total world manufacturing trade, the degree of dependence of East Asia on this new form of international specialisation is proportionately larger compared to North America and Europe. International production fragmentation has certainly played a pivotal role in continuing dynamism of the East Asian economies and increasing intra-regional economic interdependence. There is, however, no evidence to suggest that this new form of international exchange has contributed to lessoning the regions dependence on the global economy. On the contrary, growth dynamism based on vertical specialisation depends inexorably on extra-regional trade in final good, and this dependence has in fact increased over the years.
\end{abstract}

JEL classification: $\quad$ F15, F23, O53

Key words: $\quad$ production fragmentation, vertical specialisation, regional integration

Forthcoming in North American Journal of Economics and Finance

* Corresponding author: Tel.: 612 6125 8259; Fax: 61261253700 


\title{
Production fragmentation and trade integration: East Asia in a global context
}

\author{
Prema-chandra Athukorala*, Nobuaki Yamashita \\ Research School of Pacific and Asian Studies, The Australian National University
}

\section{Introduction}

International production fragmentation-cross-border dispersion of component production/assembly within vertically integrated production processes, with each country specialising in a particular stage of the production sequence- has been an important feature of the deepening structural interdependence of the world economy in recent decades. ${ }^{1}$ This phenomenon has reflected in a rapid growth of trade in parts and components ('middle products' or 'fragments of final goods') at a rate exceeding that of trade in final goods because a good crosses multiple borders while in the process. This paper aims to examine the extent, trends and patterns of this new form of international exchange, and its implications for analysing regional trade patterns, with special emphasis on countries in East Asia. The study is based on a systematic separation of trade in parts and components from total trade flows using a new data set extracted from the UN trade database. The East Asian experience is examined in the wider global

\footnotetext{
${ }^{1}$ This phenomenon has gone under alternative names, such as 'vertical specialisation' (Hummels et al. 2001, Yi 2003), 'slicing the value chain' (Krugman 1995), 'international production sharing' (Ng and Yeats 2001 and 2003, Yeats 2001), and 'outsourcing' (Grossman and Helpman 2005).
} 
context, focussing specifically on the comparative experience of that region, and the North American Free Trade Area (NAFTA) and the European Union (EU).

There is a vast literature based on the standard trade data analysis (which is essentially based on the traditional notion of horizontal specialisation scenario in which trade is essentially an exchange goods that are produced from start to finish in just one country) that unequivocally points to a persistent increase in intra-regional trade in East Asia (including as well as excluding Japan) form about the early 1980s (e.g., Kwan 2001, Drysdale and Garnaut 1997, Frankel and Wei 1997, Petri 1993). This evidence figures prominently in the current debate on forming regional trading arrangements covering some or all countries in East Asia. In this paper we argue that, in a context where component trade is growing rapidly, the standard trade flow analysis can lead to misleading inferences as to the nature and extent of trade integration among countries, for two reasons. First, in the presence of production fragmentation, trade data are doublecounted because goods in process cross multiple international borders in the course of their production sequence, generating international trade with each border crossing. The total amount of trade involving the goods while in process can be a multiple of the final value of that good. Second, and perhaps more importantly, trade share calculated using reported data can lead to wrong inferences as to the relative importance of the 'region' and the rest of the world for growth dynamism of a given country/region, even controlling for double counting in trade. This is because intra/extra regional patterns of trade in parts and components (henceforth refereed to as 'fragmentation trade') and trade in related final goods ('final trade') are unlikely to follow the same patterns. There is indeed ample evidence coming from the case-study literature on multinational enterprises 
operating in the East Asian region that the demand for the final products predominantly comes from the rest of the world, particularly from North America and countries in the EU. $^{2}$

This paper relates to and builds on Ng and Yeats (2001 and 2003) and Athukorala (2003). Compared to these papers, the present paper offers both more current and detailed information on the nature, trends and patterns of fragmentation trade. However, its major novelty is in the analysis of the determinants of fragmentation trade; to the best of our knowledge, this is the first analysis of the determinants of parts and component trade in a large sample of bilateral trade relations at the global level. ${ }^{3}$ Our approach is essentially empirical by design, but the empirical analysis in carried out in the context of the existing body of theoretical literature. ${ }^{4}$

The paper is organised as follows. Section 2 discusses the procedure followed in extracting data from the UN trade data tapes and data quality. Section 3 examines the nature and extent of global trade in components and East Asia's role in this form of trade specialisation. This section also deals with the implications of the rapid expansion of production fragmentation for analysing intra- and extra-regional patterns of economic integration of East Asia. Section 4 uses a 'modified' gravity model to examine determinants of bilateral trade in parts and components, focusing separately on export

\footnotetext{
${ }^{2}$ See for instance Borrus (1997); Dobson and Chia (1997); McKendrick, Doner and Haggards (2000).

${ }^{3}$ The few available studies which analysis the implications of production fragmentations with a specific regional (rather than a global) focus include Egger and Egger (2003 and 2005), Gorg (2000) and Baldone et al. (2001).

${ }^{4}$ Important contributions to the theory of production fragmentation include Arndt (1997), Jones (2000), Grossman and Helpman (2005), Jones and Kierzkowski (1990 and 2001), Venables (1999) and Yi (2003).
} 
and import sides and comparing the results with those for trade in final goods (reported trade - parts and components). The final section presents the key inferences.

\section{Data}

This study makes use of data extracted from the UN trade database based on the Revision 3 of the Standard International Trade Classification (SITC, Rev 3). In its original form (SITC, Rev 1), the UN trade data reporting system did not provide for separating fragmentation trade (parts and components) from final manufactured goods. The SITC Revision 2 introduced in the late 1970s (and implemented by most countries only in the early 1980s) adopted a more detailed commodity classification, which provided for separation of parts and components within the machinery and transport sector (SITC 7). There were, however, considerable overlap between some advanced-stage assembly activities and related final goods within the sector in the Revision 2, which made it difficult to separate fragmentation trade from total trade $(\mathrm{Ng} \text { and Yeats 2001) })^{5}$. Revision 3 introduced in the mid-1980s marked a significant improvement over Revision 2. In addition to redressing overlaps within SITC 7, this new version of SITC provided for separation of parts and components trade in the 'miscellaneous goods' sector (SITC 8). These two sectors together accounted for around $70 \%$ of total world trade during the period under study.

SITC Revision 3, despite its significant improvement over the previous version, does not provide for the construction of data series covering the entire range of activities

\footnotetext{
${ }^{5}$ For instance 'television tubes' were not separable from ' $T V c$ ' and ' computer processors' were lumped together with 'computers'.
} 
involving production fragmentation. Data reported under SITC 7 do provides a comprehensive coverage of fragmentation trade. But data for SITC 8 does not seem to fully capture fragmentation trade within that commodity category. For instance, for some products such as clothing, furniture, and leather products in which outsourcing is prevalent (and perhaps has been increasing), the related components are recorded under other SITC categorizing (e.g., pieces of textile, parts of furniture, parts of leather soles). The SITC data system does not provide adequate information to separate these components and relate them accurately to the related final product. Moreover, there is evidence that international production fragmentation has been spreading beyond SITC 7 and 8 to other areas, in particular pharmaceutical and chemical products (falling under SITC 5) and machine tools and various metal products (SITC 6). Assembly activates in software trade too have recorded impressive expansion in recent years. These are lumped together with 'special transactions' under SITC 9. So the merriment of trade in parts and components reported used in this paper are presumably downward biased. These factors cause our estimates to be downward biased, and perhaps the degree of bias may have increased over the years with the gradual spread of production fragmentation to other areas of products beyond SITC 7 and 8.

It is important to note that parts and component trade measured using the reported trade data, regardless of the downward bias involved, provides only a proxy measure of fragmentation trade. On the import side, the data capture both intermediate goods used to make goods for exports and those that are used for domestic consumption. On the export side, fragmentation-based exchange encompasses both parts and components and final goods assembled using imported parts and components. Precise measurement of 
fragmentation trade requires combining published trade data with data on the inputoutput structure of trading nations. However, the latter data are not available for a sufficient number of countries to enable us to undertake a more precise analysis of global trade patterns. ${ }^{6}$

We tabulated data from the UN trade database for the period from 1992 to 2003. We used 1992 as stating point of our data tabulation because by this time countries accounting for over 95 per cent of total world manufacturing trade had adopted the new system. Year 2003 is the most recent year for which trade data are available for all reporting countries. Given the prohibitive cost of tabulation data covering the entire period, 1992, 1996 and 2003 are chosen as the most appropriate interim years for the inter-temporal comparison of trade patterns. The list of parts and components identified at the 5-digit level for these two sectors, which provides the basis of our empirical analysis. It contains a total of 225 five-digit products - 168 products belonging to SITC 7 and 57 belonging to SITC $8 .^{7}$

For the purpose our analysis, East Asia is defined to include both Japan and developing countries in the region. The latter include the newly industrialised economies (NIEs) in North Asia (South Korea, Taiwan and Hong Kong), China and members of the Association of Southeast Asian Nations (ASEAN) Free Trade Area (AFTA). Among the AFTA member countries, only the six largest economies- Indonesia, Malaysia, the Philippines, Thailand, Singapore and Vietnam - are covered in the statistical analysis;

\footnotetext{
6 See Hummels et al (2001) for an application of the input-output technique for estimating fragmentation trade for some individual OECD countries.

7 The list is available in Athukorala (2003), Appendix A-5.
} 
Brunei, Cambodia, Laos and Myanmar are ignored because of lack of data. The UN data system does not cover Taiwan (because it is not a UN member). Vietnam has not yet started reporting data under the SITC classification. Singapore has not been reporting data on its bilateral trade with Indonesia from 1964 onwards because of political reasons. In these cases partner- import and export data are based on partner country export and import records respectively.

\section{Trends and Patterns of Production Fragmentation}

World trade in parts and components increased from $\$ 400$ billion in 1992 to over $\$ 1000$ billion in 2003, recording an annual average growth rate of 3.4\% (Table 1, Figure 1). The share of these products in total world manufacturing trade increased from $17 \%$ to $23 \%$ between these two years. Components accounted for one forth of the total increment in manufacturing trade between 1992 and 2003.

\section{Table 1 about here}

Figures 1 and 2 about here

Developed countries account for the bulk of component trade (Table 1, Figure 2). However, the share of developing countries has increased sharply over the years (form $16 \%$ to $35 \%$ on the export side and $27 \%$ to $44 \%$ on the import side between 1992 and 2003). The share of East Asia (including Japan) in total world exports of components increased persistently from $31 \%$ in 1992 to $43 \%$ in 2003 . This is despite a persistent decline in the share accounted for Japan, the dominant economy in the region, from $15 \%$ 
to $11 \%$. The share of developing East Asia (East Asia excluding Japan) increased from $16 \%$ to $31 \%$ between these two years. Within the group, all reported countries have recorded increases in world market shares. The growing importance of China and Hong Kong (henceforth jointly referred to as 'Greater China') is particularly noteworthy. The share of Greater China in total component exports increased from 6\% in 1992 to $10 \%$ in $2003 .^{8}$ The increase was even sharper on the import-side, from $7 \%$ to $16 \%$. Contrary to the popular perception of 'crowding out the 'rest' by China', this increase has been within an overall increase in exports from other newcomers in the region. Component trade of Vietnam is also growing, but it still accounts for only a minor fraction of regional trade.

Japan has persistently recorded a large trade surplus in component trade, reflecting the heavy involvement of Japanese companies in overseas assembly activities to maintain their competitiveness in final trade in third country markets (Table 1, last three columns). This reflects the unique role played by Japan in world manufacturing trade in undertaking assembly activities in overseas locations (mostly in East Asia). The EU and the US too have recorded modest surpluses. By contrast, China has been a major net importer. This comparison is generally consistent with the hypothesis that high wage countries are the major supplier of components (production of which is generally more capital intensive) while low wage countries have a comparative advantage in assembly activities (which are labour intensive) ( $\mathrm{Ng}$ and Yeats 2003). However, among the individual East Asian countries, trade positions of the Philippines and Singapore have

\footnotetext{
8 Much of Hong Kong's component trade relates to production fragmentation-based activities in the Mainland China.
} 
turned from deficits to surpluses in recent years. As we will see later, this reflects growing cross border trade in components within the region. Regional production sharing networks interact and supply one another, leading to an expansion of two-way trade in components.

Has the formation of NAFTA and the integration of some of the new countries emerged countries from the former Soviet Union with the rest of the Europe adversely affect the developing East Asia's relative position in world assembly activities? Indeed, proximity to industrial countries and relatively low wages by regional standard (though not compared to some of the East Asian countries) can be considered as added advantages of these countries compared to East Asian countries in production fragmentation based international specialisation (Egger and Egger 2005, Ng and Yeats 2003, USITC 1999, Kierzkowski 2001). The data do not, however, point to any dampening effect of exports from these countries on the relative world market position of East Asia, world market shares of Mexico and rest of Europe (EUT less EU) have increased, but at a much slower rate than that of developing East Asia. It seems that in spite of geographical proximity and tariff concessions under FTAs, US producers still find East Asia as a more attractive location for outsourcing. A new dimension of regional production sharing in Europe has been added by the economic integration in Europe.

Tables 2 presents comparative statistics on the share of component in total manufacturing exports and imports in 1992, 1996 and 2003 and their contribution to growth of manufacturing trade between these years. It is evident that the degree of dependence of East Asian countries as a group on component trade is much higher compared to all other regions in the world. A large part of the increase in manufacturing 
trade has been driven by vertical specialisation. In 2003 , components accounted for $28 \%$ of total manufacturing exports from developing East Asia, compared to the world average of $21 \%, 25 \%$ for NAFTA and $17 \%$ for the EU. Of the total increment in manufactured exports from East Asia between 1992 and 2003, over a third came from components exports. The comparable figures for NAFTA and the EU were $26 \%$ and $18 \%$ per cent respectively. Within East Asia, countries belonging to AFTA, in particular Malaysia, Philippine, Singapore and Thailand, stand out for their heavy dependence on production fragmentation for export dynamism. In 2003, pars and components accounted for over $40 \%$ of total manufacturing exports in AFTA, up from $24 \%$ in 1992 . Between these two years, the share of components in total manufacturing exports more than tripled in China (from $5.5 \%$ to $15.2 \%$ ). Interestingly, even for Taiwan and Korea, the relative importance of components in total manufacturing exports (and imports) has increased over the years, contradicting the popular belief that these countries had shifted palpably from component production to final good production over the years.

\section{Table 2 about here}

In all countries/regions covered by our data tabulations, component trade is heavily concentrated in the machinery and transport equipment sector (SITC 7) (Table 3). This sector accounts for over 90 per cent of the combined component trade of SITC 7 and SITC 8 (miscellaneous manufacturing). Within SITC 7, both component exports and imports of East Asia are heavily concentrated in electronics and electrical industries. Semiconductors and other electronics components (components within SITC 776) alone 
accounted for $40 \%$ of components exports from East Asia in 2003. Adding to these items components of telecommunication equipment (SITC 764) and office and automated data processing machines (SITC 759) increases the concentration ratio to almost 90 per cent of total exports of components. The balance consists largely of electrical machinery (SITC 778) and auto parts (SITC 784). The degree of concentration of component trade on electronics is much larger in AFTA (over 60\%) compared to the regional average. These electronics and electrical products are also the major areas of activity in other countries/regions. But trade patterns of these countries/regions are characterised by a greater presence of other items such as engines and motors (SITC 714), specialized industrial machinery (SITC 728), internal combustion machines (SITC 713) for which transportation cost is presumably an important consideration for production location. Overall, these differences are consistent with East Asia's competitive edge in component specialisation in electrical and electronic industries.

\section{Table 3 about here}

\section{Table 4 about here}

Table 4 compares regional patterns of total manufacturing trade and trade in components. In terms of the conventionally used trade data, intra-regional manufacturing trade (export + imports) in East Asia is significant and growing rapidly. The share of total intra-regional trade in East Asia increased from $44.1 \%$ in 1992 to $53.2 \%$ in 2003 . Intraregional trade in developing East Asia increased from 35.1\% to $40.1 \%$ between these two years. For AFTA the magnitude of these figures is much smaller, but they point to an 
impressive, persistent increase over the years from $16.6 \%$ to $21.3 \%$. By contrast, intraregional trade share has declined (from $65.4 \%$ to $51.7 \%$ ) in EU and increased marginally (from $39.0 \%$ to $43.0 \%$ ) in NAFTA.

Unlike in EU and NAFTA, the East Asian intra-regional trade ratio camouflages a significant asymmetry in regional trade patterns on import and export sides. In 2003, intra-regional import flows amounted to 65.6 per cent of total manufacturing imports of East Asia, up from 55.2\% percent in 1992. Intra-regional share in total regional exports was significantly lower, $36.6 \%$ in 1992 and $45.6 \%$ in 2003 . In other words, the region is much more heavily dependent on extra-regional trade for its growth dynamism than is (misleadingly) suggested by the total regional trade share, and this dependence has remained virtually unchanged for the last decade. This imbalance in intra-regional trade is largely a reflection of the unique nature of Japan's involvement in fragmentation trade in East Asia. As already noted, Japan's trade relations with the rest of East Asia is predominantly in the form of using the region as an assembly base for meeting demand in the region and, more importantly for exporting to the rest of the world. Japan has persistently maintained a trade surplus with all East Asian countries in both total manufacturing trade and trade in component, of which the latter is much larger (data not reported for brevity).

Component trade accounts for a significant and growing share of intra-regional trade in manufacturing in East Asia, both on export and import sides. Moreover, the share of components in intra-regional trade is much larger than the comparable figures for the region's extra regional trade (Table 4). In 2003, components accounted for $65 \%$ of intraEast Asian exports, compared to $46 \%$ in the region's total exports. The significance of 
component trade looms even larger for developing East Asia and in particular for the member countries of the ASEAN. According to country-level data (not reported here for brevity), cross-border component trade accounts for more than a half of total imports and exports in Singapore, Malaysia and the Philippines, and more than a third in Thailand. Korea and Taiwan are also involved in sizable cross border trade with the other countries in the region. For all East Asian countries, the share of components in both intra-regional exports and imports have increased at a much faster rate compared that in exports to and imports from countries outside the region.

So far, we have noted two important peculiarities of trade patterns in East Asia compared total global trade and trade of EU and NAFTA. Firstly, component trade has played a much more important role in trade expansion in East Asia relative to the overall global experience and experiences of countries in other major regions. Second, trade in components accounts for much larger share in intra-regional trade compared to region's trade with the rest of the world. Given these two peculiarities, trade flow analysis based on reported trade data is bound to yield a misleading picture as to the relative importance of intra-regional trade relations (as against global trade) in the growth dynamism of East Asia (and AFTA and other subregional groupings therein). Data reported in Table 5 on intra-regional shares of trade in total manufacturing, components and final goods for various regional economic groupings help understand this important point.

\section{Table 5 about here}


The intra-regional share of final manufacturing trade in East Asia declined from $52.5 \%$ in 1992 to $47.6 \%$ in 2003 , in sharp contrast to a notable increase (from $44.1 \%$ to $53.2 \%$ ) recorded by the conventionally used trade share (which covers both components and final goods). While the difference between intra-regional shares of final and total trade is observable for both exports and imports, the magnitude of the difference is much larger on the export side. The difference in magnitude between regional trade shares estimated in gross and net terms is much larger for developing East Asia and ASEAN compared to estimates for the entire region. In 2003 only $30 \%$ of final goods exports from developing Asia found markets within the region, compared to $37.6 \%$ in total exports. For AFTA the relevant figures were $17.0 \%$ and $21.7 \%$, respectively. Moreover, as already noted, for all East Asian countries Japan is a much smaller market for final goods exports, accounting for less than $10 \%$ in all cases in 2003 , compared to the USA and the EU. It is also interesting to note that, unlike in the case of East Asia (or developing East Asia and AFTA), the estimated intra-regional trade share for NAFTA, the EU and the other regional groupings are remarkably resilient to the inclusion or exclusion of component trade.

In sum, the estimates presented in this section support the hypothesis that, in a context where fragmentation based trade in expanding rapidly, the standard trade flows analysis can lead to misleading inferences regarding the on-going process of economic integration through trade. Product fragmentations leads to double-counting of trade flows in published trade data because goods in process cross multiple international borders in the course of their production sequence. The total amount of trade involving the goods while in process can be a multiple of the final value of that good. Moreover, 
trade shares calculated using reported data can lead to wrong inferences as to the relative importance of the 'region' and the rest of the world for growth dynamism of a given country/region, even controlling for double counting in trade. This is because the rate of expansion of component trade depends crucially on the demand for the related final goods. When data on component trade are excluded from trade flows, our estimates suggest that extra-regional trade is much more important than intra-regional trade for continued growth dynamism of East Asia, both including and excluding Japan. Thus, the ongoing process of product fragmentation seems to have strengthened the case for a global, rather than a regional, approach to trade and investment policymaking.

\section{Determinants of fragmentation trade}

We observed in the previous section the growing importance of fragmentation trade for trade expansion in East Asia relative to the overall global experience and experiences of countries in other major regions. We now turn to a more formal examination of what forces shape inter-country/inter-regional differences in growth of fragmentation trade. The analytical tool used for this purpose is the standard gravity model of bilateral merchandise trade that has been widely used as the 'workhorse' for empirical analysis of international trade flows. The standard gravity model postulates that trade between two countries, like the gravitational force between two masses, is a function of their economic size and the geographic distance between them. We augment this basic by adding a number of explanatory variables informed by the theory of international production fragmentation. Our specification of the gravity model is: 
$\ln X M_{i, j}=\alpha+\beta_{1} \ln G D P_{i}+\beta_{2} \ln G D P_{j}+\beta_{3} \ln P G D P_{i}+\beta_{4} \ln P G D P_{j}+$ $\beta_{5} \ln \left|\Delta P G D P_{i, j}\right|+\beta_{6} \ln D S T_{i, j}+\beta_{8} L N G_{i, j}+\beta_{9} B R D_{i, j}$

$+\delta_{1} R W G_{i}+\sum_{k} \eta_{1}$ int $R T A I N T_{i, j, k}+\sum_{k} \eta_{2} R T A E X T_{i, j, k}+\delta_{1} S I N G+\delta_{2} I R E$ $+\phi_{1} E A S I N T+\phi_{2}$ EASEXT $+\gamma T+\varepsilon_{i, j}$.

where subscripts $i$ and $j$ refer to the reporter and the partner country in bilateral trade relation and the variables are listed and defined below, with the postulated sign of the regression coefficient for the explanatory variables in brackets.

$X M \quad$ Bilateral trade (export or import) between $i$ and $j$

GDP Real gross domestic product (GDP), a measure of the economic size $(+)$

PGDP Real GDP per capita $(+)$

$\mid \Delta$ PGDP $\mid$ Absolute difference in GDP per capita (- or + )

DST The distance between $i$ and $j(-)$

$B R D \quad$ A dummy variable which is unity if $i$ and $j$ share the same border $(+)$

RWG An index of relative manufacturing wage of $i$ (manufacturing wage in $i$ relative to that of $j$, adjusted for the bilateral exchange rate) (- for exports, + for imports)

LNG A dummy variable which is unity if $i$ and $j$ have a common language and zero otherwise $(+)$

RTAINT A dummy which is unity if both $i$ and $j$ belong to the same $k$ th Regional Trade Agreements (RTA) (+)

RTAEXT A dummy taking unity when only $i$ belong to kth RTA (- or + )

SING A dummy variable taking unity for bilateral trade involving Singapore and zero otherwise $(-$ or +$)$ 
IRE A dummy variable taking unity for bilateral trade involving Ireland and zero otherwise $(-$ or +$)$

EASINT A dummy variable which is unity if $i$ and $\mathrm{j}$ are situated in East Asia $(+)$, EASEXT A dummy taking unity when only i is in East Asia (- or +)

$T \quad$ A set of time dummy variables to capture year-specific 'fixed' effects

$\alpha \quad$ A constant term

$\varepsilon \quad$ An stochastic error term, representing the omitted other influences on bilateral trade

The use of GDP as an explanatory variable of bilateral trade flows is normally justified by the modern theory of trade under imperfect competition (monopolistic competition model of trade); one will chose to trade more with a large country than with a small country because it has more variety to offer and customers like variety. The use of this variable is also consistent with the theory of international production fragmentation, which predicts that the optimal degree of fragmentation depends on the size of the market because the scale of production would determine the length to which such division of labour can proceed (Jones et al. 2004). The size of GDP can also be treated as a proxy for the market thickness (the economic depth of trading nations) which positively impact on the location of outsourcing activity (Grossman and Helpman 2005). There are also reasons to believe that GDP per capita also has a positive effect over an above the effect of GDP, as countries grow richer, the scale of output of industries become conducive to fragmentation. In addition, more developed countries have better 
ports and communication systems that facilitate trade by reducing the cost of maintaining 'services links' involved in vertical specialisation. ${ }^{9}$

The choice of absolute difference in per capita GDP and relative manufacturing wage $(R W G)$ as explanatory variables is based on the standard comparative advantage explanation of trade flows. The former variable aims to capture technology differences between countries in explaining trade patterns. Relative labour cost (adjusted for exchange rate differential) is presumably a major factor impacting on the global spread of fragmentation-based (vertical) specialisation (Jones 2000).

Distance is included as a proxy for transport (shipping) costs and other costs associated with time lags such as Internet charges, spoilage and costs associated with physical distance such as ignorance of foreign customs and tastes. Technological advances during the post-war era has certainly contributed to a 'death of distance' ( $a$ la Cairncross 1997) when it comes to international communication cost. However, there is evidence that the geographical 'distance' is still a key factor in determining international transport cost, in particular shipping cost (Hummel 1999). Distance can in fact be a

\footnotetext{
9 In gravity-model analysis of bilateral trade flows, the GDP variables are usually presented in two multiplicative terms, i.e. $G D P_{i} * G D P_{j}$ and $P G D P_{i} * P G D P_{j}$. This practice has the advantage of avoiding the statistical problems of possible multicollinearity, and heteroscadasticity (resulting from the presence of effects between extremely large countries and extremely small ones) in model estimation. But there is no theoretical justification for constraining change in partner country and reporting country GDP and PGDP to have the same degree of effect on bilateral trade flows, particularly when it comes to trade in components. In this study we, therefore, include reporting- and partner-country GDP and PGDP as separate variables. In this we closely follow (Soloaga and Winters 2001). This variable specification is, in fact, amply supported my our estimation results (Table 6); the homogeneity restriction does not hold for the coefficients on $G D P_{i}$ and $G D P_{j}$, and $P G D P_{i}$ and $P G D P_{j}$ is all four equations.
} 
more important influence on vertical trade compared to final trade because of multiple boarder-crossing involved in the value added chain.

A common border dummy $(B R D)$ is included to capture possible additional advantages of proximity that are not captured by the standard distance measure (the greater cycle distance between capital cities). A common language dummy (LNG) in included to capture the possibility that the use of a common language can facilitate trade by reducing transaction cost and better understanding of each others' culture and legal systems.

We include intra- and extra-regional dummy variables to capture the possible trade effects of membership in six regional trading agreements-AFTA, EU, NAFTA, MERCOSUR, ANDEAN and CER (with CER treated as the base dummy). Vertically specialised goods or goods in process crosses multiple international borders while they are being produced. For each RTA, the intra (insider) captures the implication of membership for trade within the RTA and the extra (outsider) dummy the likely implications for trade with the rest of the world. A positive coefficient on RTAIN suggests that the RTA tends to generate more trade to its members. The coefficient for the extra-bloc trade (RTAEXT) indicates the degree of trade-diverting effect of the RTA. The sign of the regression coefficient on this variable can go either way.

Vertical trade is postulated to be relatively more sensitive to tariff changes (under an RTA or otherwise) compared to final trade (or total trade as captured in published trade data) ((Yi 2003). Normally a tariff is incurred each time a goods in process cross a border. Consequently, when one percentage point reduction in tariff, the cost of production of a vertically-integrated good declines by a multiple of this initial reduction, 
in contrast to a one percent decline in the cost of a regular traded good. Moreover, because of tariff reduction it may also make more profitable for goods that were previously produced in entirely in one country to now become vertically specialised. Consequently, the trade stimulating effect of FTA would be higher for parts and component trade than for normal trade, other things remaining unchanged. In the case of final trade, the coefficient of the extra-regional dummy variable can go either way. However, in the case of fragmentation trade one can assumes a positive coefficient because any positive effect of an RTA on the depth of regional outsourcing activity has the potential to promote such activities extra-regionally as well (assuming of course the nature of 'rules or origin' built into the RTA).

Dummy variables are added for Singapore and Ireland to capture their pivotal role as outsourcing centres in Asia and Europe respectively. This variable choice is rooted in the new economic geography view that postulate agglomeration of activity in a few more developed sites, until the rising wags (and other cost disadvantages) outweigh the advantages of being located with other firms make it worthwhile for the marginal firm to set up elsewhere (Krugman 1995, Navaretti and Venables 2004).

Finally, intra- and extra-regional dummy variables are included for the entire East Asian region to test whether the striking importance of the region as a centre of vertical trade (as observed in Section 3) still holds when controlled for the other relevant variables.

An important variable suggested by the theory of production fragmentation (Jones 2000, Jones and Kierzkowski 1990) but not included in our set of explanatory variables is the cost of service links. Changes in such cost are associated with technological 
improvements that are quite similar across countries, and therefore cannot be explicitly captured in an empirical analysis of the determinants of bilateral trade flows. In our model the impact of such changes are accounted as part of the time-specific fixed effects (T).

We estimate the model with annual data for 36 countries (see Appendix Table A2) for the period of 1992 to 2001 . The trade data relates to the machinery and transport equipment of the UN Standard International Trade Classification system (SITC Section 7). ${ }^{10}$ As already noted, the separation of components from final goods is incomplete for other Sections of the SITC system. By focussing solely on SITC 7, we aim to minimise any bias in estimates arising from this incomplete commodity coverage of the original data. The prime focus of our analysis is on vertical trade (trade in components). However, we estimate the model for reported (total) trade and final trade (reported trade - vertical trade) as well for the purpose of comparison. Under each category, exports and imports are treated separately (rather than using a composite trade variables as the dependent variable, as is commonly done in trade flow analysis based on the gravity model), to allow for the possible difference in the nature/magnitude of the postulate impact of a given explanatory variable on bilateral import flows and export flows.

The model was estimated using ordinary least squares (OLS). Since there was strong evidence of heteroscadasticity, we derived consistent variance-covariance standard errors of the regression coefficients using the Huber-While 'sandwich' estimator. The results are reported in Table 6. Information on variable construction and the data source

\footnotetext{
${ }^{10}$ Country/time coverage of the data set is entirely dictated by the nature of data availability.
} 
are summarised in Appendix Table A-1. The countries covered and the classifications used in the construction of regional and RTA dummies are given in Appendix Table A-2.

\section{Table 6 about here}

As in many other applications of the gravity model to bilateral trade flows, in all six regressions the coefficients on the two central gravity variables - the level of GDP and the distance - have the expected signs (positive and negative, respectively) and are significant at the $1 \%$ level. However, the magnitude of the coefficient is far from homogenous across the three types of trade flows (components, final goods and total trade) and between export and import flows under each type. For instance, GDP of the partner country seems to have a much larger effect on imports compared to exports. For parts and component trade, this result is consistent with the fact (as observed in Section 3) that, in component trade, countries generally tends to specialise in a narrow range of product lines.

The results for the distance variable provide strong support for the hypothesis that cost of transportation and other distance-related costs are an important determinant of trade flows. As can be expected, the magnitude of the coefficient is remarkably similar for export and import flows. Interestingly, the coefficient on both import and export side for components are much larger in magnitude compared to those relating to final trade. ${ }^{11}$ This difference is consistent with the hypothesis that vertical specialisation, given the multiple border crossing involved in the production process, is much more sensitive to

11 The difference is statistically significant in both cases. 
transport cost. The common language dummy is statistically significant with the expected positive sign in all cases as expected.

The coefficient on $R W G$ is statistically significant with the expected sign in both export and import equations. Thus, there is strong empirical support for the hypothesis that relative wage differentials are a significant determinant of cross border trade in components (as well as the related final products). Interestingly the magnitude of the coefficient is remarkably similar across all equations. This may reflect the interconnectedness of components imports and export and the dependence of final exports on component imports. The coefficient on $|\Delta \mathrm{PGDP}|$ is statistically significant in both equations, but its sign suggests that that inter-country difference in the level of technological advancement is related negatively with bilateral trade flows. ${ }^{12}$ This unexpected result may reflect the fact that developed countries still account for much of world trade in both components and final goods.

Among the regional/RTA dummies, both the intra- and extra- regional dummies are highly significant for AFTA with the positive sign in all regressions. The coefficient in the component import equation suggests that intra-AFTA is about eleven times higher than predicted by the other explanatory variables in the model. ${ }^{13}$ According to the results for the extra-regional dummy, AFTA members' trade with the rest of the world is about three times higher than the norm set by the other explanatory variables in the model. It seems that the rapid expansion of component trade within AFTA (as we observed in

\footnotetext{
${ }^{12}$ The overall regression results are not sensitive to the exclusion/inclusion of this variable.

${ }^{13}$ Note that, as the model was estimated in logs, the percentage equivalent for any dummy coefficient is, [exp (dummy coefficient) -1$]^{*} 100$.
} 
section 3) is complementary to its involvement in vertical specialisation at the global level. The regression coefficient of the Singapore dummy is also statistically significant, suggesting that the level of component trade in that country is about twice than the regression norm (including the overall AFTA factor).

Interestingly, the results for the dummy variables (both extra- and intra-regional) for the other four RTAs are rather mixed. In most cases, the coefficients carry the unexpected (negative) sign and many coefficients are not statistically different from zero. Overall, there is no evidence to support the hypothesis that RTAs promote vertical specialisation. This result is consistent with the fact that much of the fragmentation trade in the world since as early as 1960s has taken place under tariff concessions (overseas assembly provisions of developed countries and export promotion schemes of developing countries). Formation of RTAs would therefore have simply resulted in substituting for the existing tariff concessions rather that generating new incentives for fragmentation trade (Egger and Egger 2005). Against this backdrop, the unique results for AFTA (and Singapore) clearly points to the need for going beyond intra-regional tariff reductions (and other variables captured in our model) to understand that region's unique dynamic role in fragmentation trade. Perhaps the explanation lies in economic history, the early choice of the region (firstly Singapore and subsequently Malaysia and other countries) by MNEs as a location of outsourcing activities. It is well known that there is a general tendency for MNE affiliates to become increasingly embedded in host countries the longer they are present there and the more conducive the overall investment climate of the host country becomes over time. They may respond sluggishly to relative cost changes once they have invested substantial resources in domestic production facilities 
and in establishing information links. Moreover, site selection decisions of MNEs operating in assembly activities are strongly influenced by the presence of other key market players in the given country (Rangan and Lawrence 1999).

Finally, there is no evidence to suggest that East Asia is a 'natural trading bloc' for fragmentation trade. When controlled for intra-AFTA trade, the coefficient on the intra-regional East Asia dummy on the component export equation is statistically significant with the negative sign on the component export equation, whereas it is not statistically different from zero on the import equation. These estimates are consistent with our earlier inference (Section 3) that the regional component trade is lopsided in that its growth dynamism come predominantly from extra-regional trade.

\section{Conclusions}

There is clear evidence that fragmentation trade is expanding more rapidly than conventional final-good trade. The degree of dependence on this new form of international specialisation is proportionately larger in East Asia compared to North America and Europe. This seems to be the outcome of the relatively more favourable policy setting for international production, agglomeration benefits arising from the early entry into this new form of specialisation, and considerable inter-country wage differential in the region. A notable recent development in international production fragmentation in the region has been the rapid integration of China into the regional production networks. This development is an important counterpoint to the popular belief that China's global integration would crowd out other countries' opportunities for international specialization. 
International production fragmentation has certainly played a pivotal role in continuing dynamism of the East Asian economies and increasing intra-regional economic interdependence. This does not, however, mean that the process has contributed to lessoning the regions dependence on the global economy. The high intraregional trade reported in recent studies reflects rapidly expanding intra-regional trade in components. There is no evidence of rapid intra-regional trade integration in terms of final products. In fact, the region's growth dynamism based on vertical specialisation depends inexorably on its extra-regional trade in final good, and this dependence has in fact increased over the years. The growing importance of China both as a regional exporter and importer has begun to change the picture in recent years, but extra-regional trade is likely to remain the engine of growth of the region in the foreseeable future. Put simply, growing trade in components has made the East Asia region increasingly reliant on extra-regional trade for its growth dynamism. In this context, these countries would be better off by upholding universal principles of economic openness. 


\section{Acknowledgements}

This is the revised version of a paper presented at the workshop on Regional Integration with Particular Reference to Asia, Claremont McKenna College, Claremont, CA, USA, 25, February 2005. The authors would like to thank Sven Arndt, Ronald Jones, Ramkishan Rajan, Jong-Wha Lee and the anonymous referee for useful comments.

\section{References}

Arndt, S. W. (1997). Globalization and the open economy. North American Journal of Economics and Finance, 8 (1), 71-79.

Athukorala, P. (2003). Product fragmentation and trade patterns in East Asia'. Trade and Development Discussion Paper 2003/21, Division of Economics, Research School of Pacific and Asian Studies, The Australian National University, Canberra.

Baldone, S., Sdoagati, F. \& Tajoli, L. (2001). Patterns and determinants of international fragmentation of production: evidence from outward processing trade between the EU and Central Eastern European countries. Weltwirtschaftliches Archiv, 137 (1), 80-104.

Borrus, M. (1997). Left for dead: Asian production networks and the revival of US electronics. In B. Naughton (Ed.), The China circle: economics and technology in the PRC, Taiwan and Hong Kong (139-163). Washington DC: Brookings Institution Press.

Cairncross, F. (1997). The death of distance: how the communication revolution will change our lives. London: Orion Business Books. 
Dobson, W. \& Chia, S. Y. (1997). Multinationals and East Asian integration. Singapore: Institute of Southeast Asian Studies.

Drysdale, P. \& Garnaut, R. (1997). The pacific: an application of a general theory of economic integration. In C. F. Bergsten \& M. Noland (Eds.), Pacific dynamism and the international economic system (pp.183-224). Washington DC: Institute for International Economics.

Egger, H. \& Egger, P. (2003). Outsourcing and skill-specific employment in a small economy: Austria after the fall of the iron curtain. Oxford Economic Papers, 55 (4), 625-643.

Egger, H. \& Egger, P. (2005). The determinants of EU processing trade. World Economy, $28(2), 147-168$.

Frankel, J. A. \& Wei, S. (1997). The new regionalism and Asia: impact and policy options. In A. Panagariya, M.G. Quibria \& N. Rao (Eds.), The global trading system and developing Asia (pp. 83-130). Oxford: Oxford University Press.

Gorg, H. (2000). Fragmentation and trade: US inward processing trade in the EU. Weltwirtschaftliches Archiv, 136 (3), 403-422.

Grossman, G. M. \& Helpman, E. (2005). Outsourcing in a global economy. Review of Economic Studies, 72 (1), 135-159.

Hummels, D. (1999). Have international transport cost declined? Graduate School of Business, University of Chicago (paper in progress).

Hummels, D., Ishii, J. \& Yi, K. (2001). The nature and growth of vertical specialization in world trade. Journal of International Economics, 54 (1), 75-96. 
Jones, R. W. (2000). Globalization and the theory of input trade. Cambridge, Mass.: MIT Press.

Jones, R. W. \& Kierzkowski, H. (1990). The role of services in production and international trade: a theoretical framework. In R.W. Jones \& A. O. Krueger (Eds.), The political economy of international trade: essays in honor of Robert Baldwin (pp. 31-48). Oxford: Basil Blackwell.

Jones, R. W. \& Kierzkowski, H. (2001). Globalization and the consequences of international fragmentation. In R. Dornbusch, G. Calvo \& M. Obstfeld (Eds.), Money, factor mobility and trade: the festschrift in honor of Robert A. Mundell (pp. 365-381). Cambridge, Mass.: MIT Press.

Jones, R. W., Kierzkowski, H. \& Lurong, C. (2004). What does the evidence tell us about fragmentation and outsourcing. International Review of Economics and Finance, $14(3), 305-316$.

Kwan, C.H. (2001). Yen bloc: toward economic integration in Asia. Washington DC: Brookings Institution Press.

Kierzkowski, H. (2001). Joining the global economy: experience and prospects of the transition economies. In S.W. Arndt \& H. Kierzkowski (Eds.), Fragmentation: new production patterns in the world economy (pp. 231-253). Oxford: Oxford University Press.

Krugman, P. (1995). Growing world trade: causes and consequences. Brooking Papers on Economic Activity, 25th Anniversary Issue, 327-377. 
McKendrick, D. G., Doner, R. F. \& Haggard, S. (2000). From Silicon Valley to Singapore: location and competitive advantage in the hard disk drive industry. Stanford, Cal: Stanford University Press.

Navaretti, G. B. \& Venables, A. J. (2004). Multinational firms in the world economy. Princeton, NJ: Princeton University Press.

Ng, F. \& Yeats, A. (2001). Production sharing in East Asia: who does what for whom, and why? In L. K. Cheng \& H. Kierzkowski (Eds.), Global production and trade in East Asia (pp. 63-109). Boston: Kluwer Academic Publishers.

Ng, F. \& Yeats, A. (2003). Major trade trends in East Asia: what are their implications for regional cooperation and growth?. Policy Research Working paper 3084, Washington DC: World Bank.

Petri, P. (1993). The East Asian trading block: an analytical history. In J. A. Frankel \& M. Kahler (Eds.), Regionalism and rivalry: Japan and the United State in Pacific Asia (pp. 21-48). Chicago: Chicago University Press.

Rangan, S. \& Lawrence, R. (1999). A prism on globalization. Washington DC: Brookings Institution Press.

Soloaga, I. and Winters, L.A. (2001). Regionalism in the nineties: What effect on trade?. North American Journal of Economics and Finance, 12(1), 1-29.

USITC (United State International Trade Commission) (1999). Production sharing: use of U.S. components and material in foreign assembly operations, 1995-1998. USITC Publication 3265, Washington DC: USITC. 
Venables, A. J. (1999). Fragmentation and multinational production. European Economic Review, 43 (3), 935-945.

Yi, K. (2003). Can vertical specialization explain the growth of world trade. Journal of Political Economy, 111 (1), 52-102. 
Table 1

World Trade in Parts and Components, 1992-2003 (\%)

\begin{tabular}{|c|c|c|c|c|c|c|c|c|c|}
\hline & \multicolumn{3}{|c|}{ Exports } & \multicolumn{3}{|l|}{ Imports } & \multicolumn{3}{|c|}{ Trade balance } \\
\hline & 1992 & 1996 & 2003 & 1992 & 1996 & 2003 & 1992 & 1996 & 2003 \\
\hline East Asia & 30.6 & 38.3 & 42.7 & 25.5 & 32.8 & 41.5 & 23.9 & 11.0 & 3.1 \\
\hline Japan & 14.9 & 15.5 & 11.2 & 3.4 & 4.7 & 4.4 & 78.8 & 68.4 & 60.7 \\
\hline Developing East Asia & 15.8 & 22.8 & 31.5 & 22.1 & 28.0 & 37.1 & -27.9 & -28.1 & -17.4 \\
\hline China & 0.8 & 1.7 & 5.7 & 2.6 & 2.9 & 10.1 & -191.7 & -78.5 & -76.9 \\
\hline Hong Kong SAR & 3.1 & 0.9 & 6.0 & 3.8 & 4.6 & 6.3 & -10.9 & -408.9 & -5.1 \\
\hline Rep. of Korea & 2.5 & 3.8 & 4.1 & 3.0 & 3.3 & 3.4 & -7.5 & 10.5 & 18.3 \\
\hline Taiwan & 2.9 & 4.5 & 3.2 & 3.0 & 2.8 & 5.3 & 3.2 & 36.0 & -65.4 \\
\hline AFTA & 6.4 & 11.8 & 12.5 & 9.6 & 14.5 & 12.0 & -37.7 & -27.8 & 4.3 \\
\hline Indonesia & 0.1 & 0.3 & 0.4 & 0.9 & 0.9 & 0.3 & -517.5 & -259.3 & 27.5 \\
\hline Malaysia & 2.2 & 3.4 & 3.2 & 2.7 & 3.8 & 3.5 & -9.5 & -16.0 & -7.9 \\
\hline Philippines & 0.2 & 1.2 & 2.0 & 0.5 & 1.5 & 1.8 & -144.3 & -24.0 & 8.1 \\
\hline Singapore & 2.9 & 5.6 & 5.4 & 3.9 & 6.0 & 4.7 & -22.9 & -10.3 & 12.2 \\
\hline Thailand & 0.9 & 1.2 & 1.5 & 1.7 & 2.3 & 1.6 & -65.1 & -89.5 & -9.2 \\
\hline Vietnam & 0.0 & 0.0 & 0.1 & 0.0 & 0.1 & 0.1 & -1275.0 & -371.7 & -155.6 \\
\hline South Asia & 0.1 & 0.2 & 0.2 & 0.7 & 0.4 & 0.6 & -376.0 & -146.3 & -162.4 \\
\hline CER & 0.1 & 0.4 & 0.4 & 0.3 & 1.3 & 1.0 & -219.3 & -218.5 & -166.3 \\
\hline NAFTA & 25.4 & 24.0 & 21.5 & 25.5 & 25.8 & 22.3 & 8.2 & -11.8 & -3.2 \\
\hline USA & 20.4 & 18.7 & 16.3 & 17.6 & 17.7 & 14.4 & 21.0 & 1.7 & 11.9 \\
\hline Canada & 3.5 & 3.3 & 2.6 & 5.9 & 5.2 & 4.0 & -53.3 & -61.2 & -54.1 \\
\hline Mexico & 1.5 & 1.9 & 2.7 & 2.0 & 2.9 & 3.9 & -21.0 & -58.2 & -46.7 \\
\hline MERCOSUR & 0.6 & 0.6 & 0.5 & 1.1 & 1.6 & 1.0 & -85.0 & -185.3 & -114.4 \\
\hline Andean Pact & 0.0 & 0.0 & 0.0 & 0.5 & 0.3 & 0.2 & -1232.9 & -783.6 & -445.0 \\
\hline Europe & 45.3 & 53.9 & 36.2 & 46.6 & 49.7 & 34.8 & 6.0 & 4.2 & 4.2 \\
\hline EU & 43.0 & 38.0 & 32.2 & 43.4 & 33.8 & 30.2 & 7.7 & 7.6 & 6.4 \\
\hline Eastern Europe & 0.3 & 0.9 & 2.4 & 0.5 & 1.4 & 2.8 & -28.2 & -46.6 & -13.6 \\
\hline Rest of Europe & 2.0 & 1.7 & 1.6 & 2.7 & 2.1 & 1.8 & -25.3 & -22.3 & -12.1 \\
\hline World & 100.0 & 100.0 & 100.0 & 100.0 & 100.0 & 100.0 & & & \\
\hline$\$$ billion & 447 & 729 & 1048 & 408 & 756.9 & 1044 & & & \\
\hline \multicolumn{10}{|l|}{ Memorandum Items } \\
\hline Developed countries & 84.1 & 75.7 & 64.7 & 73.3 & 65.5 & 55.8 & 20.4 & 16.3 & 14.0 \\
\hline Developing countries & 15.9 & 24.3 & 35.3 & 26.7 & 34.5 & 44.2 & -54.2 & -37.5 & -24.7 \\
\hline
\end{tabular}

Note: By definition percentage shares in exports and imports for a given year should be identical. The minor differences seem to reflect recording errors and differences in merriment arising from the use of CIF price for reporting imports and FOB price for reporting exports.

Source: Compiled from UN Comtrade database. 
Table 2

Parts and Components $(\mathrm{P} \& \mathrm{C})$ in Manufacturing Trade

(A) Exports

\begin{tabular}{|c|c|c|c|c|c|c|c|c|c|}
\hline \multirow[t]{2}{*}{ Country/region } & \multicolumn{3}{|c|}{$\begin{array}{l}\text { Value of P\&C } \\
\text { ( } \$ \text { billion) }\end{array}$} & \multicolumn{3}{|c|}{$\begin{array}{l}\text { Share of P\&C in } \\
\text { mfg. exports }\end{array}$} & \multirow{2}{*}{$\begin{array}{l}\begin{array}{l}\text { Groth of } \\
\text { mfg. } \\
\text { exports }\end{array} \\
1992-03\end{array}$} & \multirow{2}{*}{$\begin{array}{l}\begin{array}{l}\text { Growth } \\
\text { of P\&C } \\
\text { exports }\end{array} \\
1992-03 \\
\end{array}$} & \multirow{2}{*}{$\begin{array}{l}\begin{array}{l}\text { Contribution } \\
\text { of } P \& C \text { to } \\
\text { growth of } \\
\text { mfg exports }\end{array} \\
1992-03\end{array}$} \\
\hline & 1992 & 1996 & 2003 & 1992 & 1996 & 2003 & & & \\
\hline East Asia & 136.8 & 275.8 & 447.5 & 19.2 & 28.0 & 27.9 & 3.2 & 4.8 & 34.9 \\
\hline Japan & 66.5 & 106.1 & 117.4 & 21.2 & 30.2 & 27.9 & 1.2 & 2.3 & 47.1 \\
\hline Developing East Asia & 70.4 & 169.7 & 330.1 & 17.5 & 26.7 & 27.9 & 4.4 & 6.3 & 33.2 \\
\hline China & 3.6 & 9.8 & 59.5 & 5.5 & 9.8 & 15.2 & 7.3 & 11.7 & 17.1 \\
\hline Hong Kong SAR & 14.1 & 27.9 & 62.4 & 12.9 & 26.7 & 29.3 & 2.7 & 6.1 & 46.4 \\
\hline Rep. of Korea & 11.4 & 26.7 & 43.4 & 17.1 & 25.2 & 25.5 & 3.8 & 5.4 & 30.9 \\
\hline Taiwan & 12.8 & 22.4 & 33.6 & 28.3 & 28.8 & 39.5 & 2.5 & 3.9 & 52.4 \\
\hline AFTA & 28.5 & 82.9 & 131.2 & 24.7 & 35.0 & 40.6 & 4.1 & 6.2 & 49.5 \\
\hline Indonesia & 0.6 & 1.7 & 4.3 & 3.7 & 7.4 & 13.9 & 2.7 & 8.3 & 24.5 \\
\hline Malaysia & 10.0 & 23.5 & 33.9 & 38.7 & 42.6 & 42.7 & 4.5 & 4.9 & 44.6 \\
\hline Philippines & 0.8 & 8.8 & 20.7 & 19.8 & 52.5 & 63.8 & 8.6 & 13.7 & 70.0 \\
\hline Singapore & 13.0 & 39.4 & 56.5 & 27.0 & 39.7 & 46.7 & 3.7 & 6.0 & 59.8 \\
\hline Thailand & 4.1 & 9.5 & 15.8 & 19.1 & 23.4 & 26.7 & 4.1 & 5.4 & 31.0 \\
\hline Vietnam & & & & & 5.2 & & & & \\
\hline South Asia & 0.6 & 1.0 & 2.6 & 2.6 & 4.9 & 4.0 & 4.0 & 5.8 & 4.9 \\
\hline CER & 0.3 & 4.0 & 3.8 & 13.2 & 18.9 & 17.3 & 8.9 & 10.0 & 17.8 \\
\hline NAFTA & 113.5 & 182.4 & 225.5 & 25.3 & 27.2 & 25.6 & 2.7 & 2.7 & 26.0 \\
\hline USA & 91.0 & 146.2 & 170.6 & 26.8 & 30.5 & 29.2 & 2.2 & 2.5 & 32.5 \\
\hline Mexico & 6.7 & 13.1 & 28.0 & 20.7 & 19.4 & 21.1 & 5.8 & 5.8 & 21.3 \\
\hline MERCOSUR & 2.5 & 3.8 & 4.9 & 13.1 & 13.5 & 12.2 & 3.0 & 2.6 & 11.3 \\
\hline Andean Pact & 0.2 & 0.2 & 0.4 & 5.0 & 4.1 & 5.6 & 2.9 & 3.4 & 6.2 \\
\hline Europe & 202.4 & 277.5 & 379.5 & 15.5 & 16.2 & 16.6 & 2.2 & 2.5 & 18.0 \\
\hline EU & 192.1 & 258.5 & 337.5 & 15.9 & 17.7 & 16.7 & 2.1 & 2.2 & 17.9 \\
\hline Eastern Europe & 1.5 & 6.9 & 25.4 & 9.1 & 13.5 & 20.2 & 8.4 & 11.9 & 21.9 \\
\hline Rest of Europe & 8.8 & 12.2 & 16.7 & 11.1 & 12.3 & 11.7 & 2.3 & 2.5 & 12.4 \\
\hline World & 446.7 & 729.4 & 1047.8 & 17.9 & 20.3 & 21.1 & 2.8 & 3.4 & 24.4 \\
\hline Developed countries & 375.9 & 552.4 & 677.5 & 18.6 & 20.4 & 20.2 & 2.0 & 2.4 & 22.5 \\
\hline Developing countries & 70.8 & 177.0 & 370.3 & 15.0 & 19.8 & 23.1 & 4.9 & 6.7 & 26.5 \\
\hline
\end{tabular}


(b) Imports

\begin{tabular}{|c|c|c|c|c|c|c|c|c|c|}
\hline \multirow[t]{2}{*}{ Country/region } & \multicolumn{3}{|c|}{$\begin{array}{l}\text { Value of P\&C } \\
\text { ( } \$ \text { billion) }\end{array}$} & \multicolumn{3}{|c|}{$\begin{array}{l}\text { Share of } \mathrm{P} \& \mathrm{C} \text { in } \\
\mathrm{mfg} \text {. imports }\end{array}$} & \multirow{2}{*}{$\begin{array}{l}\text { Groth of } \\
\text { mfg. } \\
\text { imports } \\
1992- \\
2003\end{array}$} & \multirow{2}{*}{$\begin{array}{l}\begin{array}{l}\text { Growth } \\
\text { of P\&C } \\
\text { imports }\end{array} \\
1992- \\
2003\end{array}$} & \multirow{2}{*}{$\begin{array}{l}\text { Contribution } \\
\text { of } \mathrm{P} \& \mathrm{C} \text { to } \\
\text { growth of } \\
\text { mfg imports } \\
1992-2003\end{array}$} \\
\hline & 1992 & 1996 & 2003 & 1992 & 1996 & 2003 & & & \\
\hline East Asia & 104.1 & 249.4 & 433.6 & 19.8 & 27.9 & 34.6 & 3.5 & 5.8 & 45.4 \\
\hline Japan & 14.1 & 31.3 & 46.2 & 14.2 & 19.3 & 21.5 & 3.1 & 4.8 & 27.7 \\
\hline Developing East Asia & 90.1 & 218.0 & 387.4 & 21.1 & 30.2 & 37.4 & 3.6 & 5.9 & 48.8 \\
\hline China & 10.6 & 20.8 & 105.3 & 17.6 & 21.1 & 34.3 & 6.6 & 9.5 & 38.4 \\
\hline Hong Kong SAR & 15.6 & 31.2 & 65.6 & 14.7 & 20.4 & 31.4 & 2.7 & 5.8 & 48.5 \\
\hline Rep. of Korea & 12.2 & 22.6 & 35.5 & 25.2 & 27.4 & 33.6 & 3.1 & 4.3 & 40.7 \\
\hline Taiwan & 12.4 & 27.5 & 55.5 & 16.9 & 35.0 & 37.3 & 2.8 & 6.1 & 57.0 \\
\hline AFTA +5 & 39.2 & 102.4 & 125.5 & 28.2 & 39.3 & 47.1 & 2.6 & 4.7 & 67.8 \\
\hline Indonesia & 3.6 & 6.7 & 3.1 & 18.5 & 23.8 & 18.5 & -0.5 & -0.5 & 18.5 \\
\hline Malaysia & 11.0 & 27.1 & 36.5 & 35.2 & 47.5 & 55.7 & 3.0 & 4.9 & 74.4 \\
\hline Philippines & 1.9 & 10.9 & 19.1 & 24.8 & 43.6 & 63.1 & 5.5 & 9.4 & 76.5 \\
\hline Singapore & 16.0 & 50.3 & 49.6 & 30.0 & 42.8 & 49.2 & 2.6 & 4.6 & 70.8 \\
\hline Thailand & 6.8 & 20.9 & 17.2 & 24.7 & 32.9 & 32.5 & 2.6 & 3.7 & 41.0 \\
\hline South Asia & 3.0 & 3.8 & 6.8 & 14.1 & 14.6 & 12.6 & 3.8 & 3.3 & 11.6 \\
\hline CER & 1.1 & 9.0 & 10.0 & 14.6 & 15.2 & 12.1 & 10.1 & 9.3 & 11.9 \\
\hline NAFTA & 104.2 & 183.9 & 232.7 & 18.9 & 23.6 & 17.7 & 3.5 & 3.2 & 16.9 \\
\hline USA & 71.9 & 126.0 & 150.3 & 17.5 & 21.7 & 15.4 & 3.5 & 3.0 & 13.8 \\
\hline Mexico & 8.0 & 20.7 & 41.1 & 18.7 & 30.6 & 28.7 & 4.9 & 6.7 & 33.0 \\
\hline MERCOSUR & 4.7 & 11.0 & 10.5 & 17.9 & 17.2 & 21.5 & 2.5 & 3.2 & 25.6 \\
\hline Andean Pact & 2.2 & 2.0 & 2.1 & 12.6 & 9.7 & 9.1 & 1.1 & -0.2 & -1.9 \\
\hline Europe & 190.3 & 267.0 & 363.4 & 15.0 & 16.6 & 17.4 & 2.0 & 2.6 & 21.1 \\
\hline EU & 177.3 & 242.0 & 315.9 & 15.3 & 18.9 & 17.6 & 1.7 & 2.3 & 21.8 \\
\hline Eastern Europe & 1.9 & 10.1 & 28.8 & 9.2 & 14.3 & 20.3 & 8.0 & 11.4 & 22.2 \\
\hline Rest of Europe & 11.1 & 14.9 & 18.7 & 12.6 & 12.5 & 12.3 & 2.2 & 2.1 & 11.9 \\
\hline World & 408.2 & 705.8 & 1044.3 & 16.8 & 19.8 & 20.7 & 2.9 & 3.8 & 24.4 \\
\hline Developed countries & 299.0 & 462.4 & 582.5 & 16.1 & 18.4 & 17.0 & 2.4 & 2.7 & 18.2 \\
\hline Developing countries & 109.2 & 243.4 & 461.8 & 19.5 & 23.0 & 28.6 & 4.3 & 5.9 & 33.5 \\
\hline
\end{tabular}

Notes:

1. By definition percentage shares in exports and imports for a given year should be identical. The minor differences seem to reflect recording errors and differences in merriment arising from the use of CIF price for reporting imports and FOB price for reporting exports.

Source: Compiled from UN Comtrade database. 
Table 3

Percentage Composition of Parts and Components Exports and Imports by three-digit SITC Categories ${ }^{1}, 2003$

\begin{tabular}{|c|c|c|c|c|c|c|c|c|c|c|c|}
\hline SITC & Export & $\begin{array}{l}\text { East } \\
\text { Asia }\end{array}$ & Japan & $\begin{array}{l}\text { Dev. } \\
\text { East } \\
\text { Asia }\end{array}$ & $\begin{array}{l}\text { China } \\
+ \text { HK }\end{array}$ & Korea & AFTA & NAFTA & Mexico & $\mathrm{EU}$ & World \\
\hline 7 & Machinery and Transport Equipment & 96.1 & 94.4 & 96.7 & 94.8 & 98.8 & 98.1 & 93.8 & 97.0 & 94.5 & 94.6 \\
\hline 713 & Internal combust piston engines & 1.0 & 2.2 & 0.5 & 0.3 & 0.7 & 0.5 & 3.2 & 9.5 & 4.3 & 2.7 \\
\hline 714 & Non-electrical engines and motors & 0.1 & 0.3 & 0.1 & 0.0 & 0.0 & 0.1 & 1.4 & 1.8 & 1.4 & 1.0 \\
\hline 723 & Civil engineering equipment & 0.8 & 0.8 & 0.8 & 0.4 & 1.0 & 1.1 & 2.9 & 2.4 & 1.7 & 1.6 \\
\hline 724 & Textile and leather machinery & 0.4 & 0.5 & 0.3 & 0.4 & 0.5 & 0.1 & 0.2 & 0.3 & 0.9 & 0.6 \\
\hline 737 & Metal working machinery & 0.2 & 0.4 & 0.1 & 0.2 & 0.1 & 0.1 & 0.3 & 0.1 & 0.7 & 0.4 \\
\hline 741 & Heating \& cooling equipment & 0.6 & 0.7 & 0.6 & 0.6 & 0.7 & 0.4 & 1.3 & 4.8 & 1.3 & 1.0 \\
\hline 742 & Pumps for liquid elevator & 0.2 & 0.4 & 0.2 & 0.2 & 0.1 & 0.1 & 0.6 & 0.3 & 1.0 & 0.6 \\
\hline 743 & Gas compressors and fans & 0.2 & 0.4 & 0.1 & 0.1 & 0.1 & 0.1 & 0.6 & 0.3 & 0.8 & 0.5 \\
\hline 764 & Telecommunication equipment & 12.4 & 8.3 & 14.0 & 21.8 & 14.5 & 5.3 & 6.0 & 12.7 & 5.4 & 8.2 \\
\hline 771 & Electrical machinery & 0.6 & 0.3 & 0.7 & 1.2 & 0.6 & 0.2 & 0.3 & 0.5 & 0.5 & 0.5 \\
\hline 772 & Apparatus for switching/protecting circuits & 5.8 & 8.2 & 4.9 & 5.8 & 2.1 & 4.5 & 6.9 & 29.2 & 9.5 & 7.5 \\
\hline 776 & Semiconductors \& other electronic components & 40.0 & 31.0 & 43.6 & 24.8 & 44.0 & 61.1 & 22.8 & 13.2 & 13.2 & 25.4 \\
\hline 778 & Electrical machinery and apparatus, n.e.s. & 3.2 & 4.0 & 2.9 & 4.3 & 3.1 & 1.3 & 2.4 & 10.8 & 2.4 & 2.7 \\
\hline 784 & Motor vehicle parts/accessories & 7.4 & 17.5 & 3.3 & 2.1 & 8.5 & 2.4 & 20.8 & 5.9 & 22.2 & 16.1 \\
\hline 785 & Motor cycle/cycle parts/accessories & 0.9 & 1.3 & 0.8 & 1.1 & 0.1 & 0.6 & 0.2 & 0.2 & 0.7 & 0.7 \\
\hline 791 & Railway vehicles \& associated equipment & 0.0 & 0.1 & 0.0 & 0.1 & 0.0 & 0.0 & 0.5 & 0.3 & 0.8 & 0.5 \\
\hline 792 & Aircrafts and associated equipment & 1.1 & 1.3 & 1.0 & 0.5 & 0.5 & 1.5 & 7.1 & 0.7 & 6.5 & 4.3 \\
\hline
\end{tabular}




\begin{tabular}{|c|c|c|c|c|c|c|c|c|c|c|c|}
\hline & Other $^{4}$ & 2.6 & 2.6 & 2.5 & 4.4 & 0.8 & 1.1 & 1.6 & 1.5 & 2.3 & 2.3 \\
\hline & Total & 100 & 100 & 100 & 100 & 100 & 100 & 100 & 100 & 100 & 100 \\
\hline & \$ Billion & 399 & 114 & 286 & 122 & 434 & 132 & 227 & 17 & 340 & 1047 \\
\hline & (b) Imports & & & & & & & & & & \\
\hline 7 & Machinery and Transport Equipment & 96.0 & 91.5 & 96.7 & 96.9 & 95.7 & 97.3 & 93.5 & 95.4 & 93.8 & 94.6 \\
\hline 713 & Internal combust piston engines & 1.3 & 1.4 & 1.2 & 0.9 & 2.3 & 1.2 & 4.3 & 3.5 & 4.1 & 3.3 \\
\hline 714 & Non-electrical engines and motors & 0.3 & 0.6 & 0.2 & 0.1 & 0.2 & 0.5 & 1.0 & 1.6 & 1.2 & 0.9 \\
\hline 723 & Civil engineering equipment & 0.9 & 0.7 & 0.9 & 0.6 & 0.1 & 1.4 & 1.2 & 0.4 & 1.4 & 1.2 \\
\hline 724 & Textile and leather machinery & 0.4 & 0.5 & 0.4 & 0.5 & 0.3 & 0.2 & 0.3 & 0.3 & 0.5 & 0.5 \\
\hline 726 & Printing/book binding machinery & 0.1 & 0.3 & 0.1 & 0.1 & 0.1 & 0.1 & 0.2 & 0.1 & 0.4 & 0.3 \\
\hline 728 & Specialized industrial machinery & 1.1 & 1.4 & 1.0 & 0.6 & 1.6 & 1.3 & 1.4 & 0.8 & 1.8 & 1.5 \\
\hline 735 & Metal working machine tools & 0.3 & 0.5 & 0.3 & 0.2 & 0.5 & 0.3 & 0.5 & 0.3 & 0.7 & 0.5 \\
\hline 741 & Heating and cooling equipment & 0.5 & 0.8 & 0.4 & 0.4 & 0.3 & 0.4 & 1.2 & 0.9 & 1.2 & 1.0 \\
\hline 742 & Pumps for liquid elevator & 0.2 & 0.3 & 0.2 & 0.1 & 0.3 & 0.2 & 0.7 & 0.3 & 0.8 & 0.6 \\
\hline 743 & Gas compressors and fans & 0.3 & 0.6 & 0.2 & 0.2 & 0.4 & 0.2 & 0.5 & 0.3 & 0.6 & 0.5 \\
\hline 744 & Mechanical handling equipment & 0.2 & 0.4 & 0.2 & 0.2 & 0.2 & 0.2 & 0.9 & 0.2 & 1.4 & 0.8 \\
\hline 745 & Non-electrical machine tools and appliances & 0.3 & 0.6 & 0.3 & 0.3 & 0.3 & 0.2 & 0.9 & 0.7 & 1.3 & 0.8 \\
\hline 759 & Office and audio data processing machines & 13.6 & 16.1 & 13.2 & 15.7 & 5.6 & 15.9 & 13.8 & 11.5 & 13.4 & 13.5 \\
\hline 764 & Telecommunication equipment & 9.7 & 10.4 & 9.6 & 13.5 & 6.8 & 4.1 & 6.6 & 8.4 & 5.6 & 7.4 \\
\hline 772 & Apparatus for switching/protecting circuits & 5.9 & 5.6 & 5.9 & 6.5 & 5.7 & 4.6 & 8.1 & 13.4 & 7.3 & 7.4 \\
\hline \multirow[t]{2}{*}{776} & Semiconductors \& other electronic components & 50.3 & 37.6 & 52.2 & 46.5 & 59.5 & 57.3 & 16.4 & 23.8 & 14.7 & 27.9 \\
\hline & Electrical machinery and apparatus, n.e.s. & 2.4 & 1.8 & 2.5 & 2.8 & 3.5 & 1.5 & 2.7 & 3.7 & 2.9 & 2.7 \\
\hline 784 & Motor vehicle parts/accessories & 4.4 & 6.6 & 4.1 & 3.8 & 5.0 & 3.8 & 26.0 & 22.1 & 22.1 & 15.9 \\
\hline 785 & Motor cycle/cycle parts/accessories & 0.3 & 0.5 & 0.3 & 0.2 & 0.1 & 0.5 & 0.6 & 0.3 & 1.1 & 0.7 \\
\hline 791 & Railway vehicles \& associated equipment & 0.1 & 0.1 & 0.1 & 0.2 & 0.1 & 0.1 & 0.5 & 0.4 & 0.7 & 0.5 \\
\hline \multirow[t]{2}{*}{792} & Aircrafts and associated equipment & 1.3 & 2.6 & 1.1 & 0.6 & 0.8 & 1.8 & 2.7 & 0.1 & 5.8 & 3.3 \\
\hline & Other & 2.1 & 2.0 & 2.2 & 2.7 & 1.9 & 1.4 & 3.0 & 2.2 & 4.8 & 3.5 \\
\hline 8 & Miscellaneous Manufacturing & 4.0 & 8.5 & 3.3 & 3.3 & 4.3 & 2.7 & 6.4 & 4.6 & 6.2 & 5.4 \\
\hline 821 & Furniture, bedding and mattress & 0.3 & 1.2 & 0.1 & 0.1 & 0.3 & 0.1 & 2.9 & 1.4 & 1.7 & 1.4 \\
\hline 874 & Measuring/checking/analysing equipment & 1.3 & 3.6 & 1.0 & 0.6 & 2.0 & 1.1 & 1.7 & 1.4 & 2.0 & 1.6 \\
\hline
\end{tabular}




\begin{tabular}{|l|l|r|r|r|r|r|r|r|r|r|r|}
\hline & Other $^{4}$ & 2.3 & 3.7 & 2.1 & 2.5 & 2.0 & 1.5 & 1.8 & 1.8 & 2.6 & 2.4 \\
\hline & & & & & & & & & & & \\
\hline & Total & 100 & 100 & 100 & 100 & 100 & 100 & 100 & 100 & 100 & 100 \\
\hline & \$ Billion & 366.6 & 46.3 & 320.3 & 170.9 & 35.5 & 125.6 & 232.9 & 41.2 & 317.4 & 1046.7 \\
\hline
\end{tabular}

Notes:

1 5-digit SITC parts and components items aggregated at the 3-digit level 2. Including Mexico (MEX).

2 Including Mexico.

3 Including EU

4 Mostly parts of clothing, optical equipment, watches and clocks and sport goods

Source: Compiled from UN Comtrade database. 
Table 4

Direction of Parts and Component Trade

\begin{tabular}{|c|c|c|c|c|c|c|c|c|c|c|c|c|c|c|c|c|c|}
\hline \multirow{2}{*}{ Exports } & \multicolumn{9}{|c|}{ A 1: Total Manufacturing exports (X) } & \multicolumn{8}{|c|}{ B1: Parts and components export (X) } \\
\hline & & EA & Japan & DEA & $\mathrm{GCH}$ & AFTA & NAFTA & EU & Total & EA & Japan & DEA & $\mathrm{GCH}$ & AFTA & NAFTA & EU & Total \\
\hline \multirow[t]{2}{*}{ East Asia (EA) $^{1}$} & 1992 & 36.6 & 4.7 & 31.9 & 17.1 & 11.5 & 30.3 & 19.6 & 100 & 44.4 & 4.2 & 40.3 & 13.3 & 22.0 & 34.1 & 15.7 & 100 \\
\hline & 1996 & 43.8 & 7.4 & 36.5 & 16.4 & 15.9 & 27.6 & 16.6 & 100 & 52.3 & 6.3 & 45.9 & 13.9 & 27.5 & 29.1 & 14.3 & 100 \\
\hline \multirow[t]{3}{*}{ Japan } & 1992 & 25.1 & 0.0 & 25.1 & 9.0 & 11.2 & 32.7 & 20.8 & 100 & 30.2 & 0.0 & 30.2 & 6.7 & 16.7 & 36.6 & 16.6 & 100 \\
\hline & 1996 & 34.4 & 0.0 & 34.4 & 10.7 & 17.0 & 30.8 & 16.2 & 100 & 39.8 & 0.0 & 39.8 & 9.2 & 23.8 & 32.9 & 13.5 & 100 \\
\hline & 2003 & 35.9 & 0.0 & 35.9 & 17.8 & 11.5 & 28.7 & 14.9 & 100 & 49.6 & 0.0 & 49.6 & 23.6 & 18.3 & 24.0 & 12.5 & 100 \\
\hline \multirow[t]{2}{*}{ East Asia (DEA) $^{2}$} & 1996 & 46.8 & 11.5 & 35.3 & 19.0 & 14.4 & 24.1 & 16.0 & 100 & 57.3 & 10.6 & 46.6 & 16.4 & 27.8 & 23.7 & 13.7 & 100 \\
\hline & 2003 & 47.3 & 10.1 & 37.2 & 23.2 & 11.2 & 23.7 & 15.4 & 100 & 68.2 & 9.6 & 58.7 & 34.0 & 20.5 & 14.4 & 11.4 & 100 \\
\hline \multirow[t]{3}{*}{ Greater China $(\mathrm{GCH})$} & 1992 & 56.4 & 2.7 & 53.8 & 45.3 & 6.5 & 19.1 & 14.7 & 100 & 80.5 & 28.1 & 52.4 & 25.0 & 10.6 & 14.6 & 14.8 & 100 \\
\hline & 1996 & 46.2 & 8.8 & 37.4 & 26.5 & 7.5 & 25.9 & 18.8 & 100 & 83.0 & 31.7 & 51.3 & 15.1 & 14.7 & 14.7 & 13.7 & 100 \\
\hline & 2003 & 39.1 & 8.7 & 30.4 & 19.0 & 6.9 & 27.7 & 20.9 & 100 & 95.6 & 26.5 & 69.1 & 16.0 & 23.6 & 8.6 & 11.0 & 100 \\
\hline \multirow[t]{2}{*}{ AFTA } & 1992 & 36.8 & 8.8 & 28.0 & 7.1 & 19.3 & 27.2 & 19.7 & 100 & 47.3 & 9.0 & 38.3 & 7.1 & 29.3 & 28.3 & 13.7 & 100 \\
\hline & 1996 & 45.0 & 11.1 & 33.9 & 8.2 & 23.6 & 23.5 & 16.0 & 100 & 51.8 & 9.5 & 42.3 & 7.7 & 32.6 & 22.6 & 14.3 & 100 \\
\hline \multirow{2}{*}{ NAFTA } & 1996 & 18.6 & 6.8 & 11.8 & 3.2 & 5.6 & 48.0 & 16.0 & 100 & 23.9 & 7.3 & 16.6 & 3.2 & 9.8 & 43.5 & 17.0 & 100 \\
\hline & 2003 & 14.9 & 4.4 & 10.5 & 3.8 & 4.5 & 55.2 & 14.4 & 100 & 23.2 & 4.5 & 18.8 & 5.2 & 10.0 & 48.6 & 13.8 & 100 \\
\hline \multirow[t]{3}{*}{$\mathrm{EU}$} & 1992 & 5.8 & 1.9 & 3.9 & 1.5 & 1.8 & 8.2 & 64.1 & 100 & 6.3 & 1.2 & 5.1 & 1.8 & 2.7 & 9.2 & 62.1 & 100 \\
\hline & 1996 & 8.0 & 2.4 & 5.7 & 2.1 & 2.6 & 8.4 & 59.4 & 100 & 9.6 & 1.6 & 7.9 & 2.3 & 4.4 & 10.1 & 55.9 & 100 \\
\hline & 2003 & 6.7 & 1.7 & 5.0 & 2.6 & 1.6 & 11.4 & 50.8 & 100 & 9.9 & 1.4 & 8.5 & 4.1 & 3.5 & 10.1 & 49.1 & 100 \\
\hline \multirow[t]{3}{*}{ World } & 1992 & 15.4 & 3.4 & 12.0 & 5.8 & 4.7 & 20.6 & 42.9 & 100 & 18.9 & 3.1 & 15.8 & 4.9 & 8.7 & 25.0 & 37.3 & 100 \\
\hline & 1996 & 19.3 & 4.4 & 14.9 & 6.2 & 6.6 & 21.2 & 37.6 & 100 & 22.9 & 4.4 & 18.5 & 1.5 & 9.9 & 48.3 & 13.8 & 100 \\
\hline & 2003 & 19.0 & 3.7 & 15.3 & 8.5 & 4.9 & 23.5 & 32.9 & 100 & 32.3 & 4.0 & 28.3 & 14.4 & 10.9 & 21.0 & 26.8 & 100 \\
\hline
\end{tabular}




\begin{tabular}{|c|c|c|c|c|c|c|c|c|c|c|c|c|c|c|c|c|c|}
\hline \multirow{2}{*}{ Imports } & \multicolumn{9}{|c|}{ A2: Total manufacturing imports (M) } & \multicolumn{8}{|c|}{ B2: Parts and components imports (M) } \\
\hline & & EA & Japan & DEA & $\mathrm{GCH}$ & AFTA & NAFTA & EU & Total & EA & Japan & DEA & $\mathrm{GCH}$ & AFTA & NAFTA & EU & Total \\
\hline \multirow[t]{2}{*}{ East Asia (EA) } & 1992 & 55.2 & 21.2 & 34.1 & 19.5 & 9.7 & 20.4 & 19.2 & 100 & 59.3 & 28.3 & 31.0 & 9.8 & 16.5 & 25.2 & 13.6 & 100 \\
\hline & 1996 & 55.7 & 19.7 & 35.9 & 17.3 & 13.1 & 20.7 & 19.1 & 100 & 59.7 & 26.3 & 33.3 & 7.9 & 18.8 & 25.2 & 13.2 & 100 \\
\hline \multirow[t]{3}{*}{ Japan } & 1992 & 29.0 & 0.0 & 29.0 & 11.9 & 9.5 & 30.9 & 27.3 & 100 & 26.9 & 0.0 & 26.9 & 4.0 & 13.7 & 49.4 & 14.6 & 100 \\
\hline & 1996 & 36.8 & 0.0 & 36.8 & 17.4 & 13.8 & 29.0 & 22.5 & 100 & 37.0 & 0.0 & 37.0 & 8.3 & 17.2 & 42.9 & 10.3 & 100 \\
\hline & 2003 & 49.5 & 0.0 & 49.5 & 29.8 & 14.0 & 20.2 & 18.2 & 100 & 52.8 & 0.0 & 52.8 & 18.7 & 21.4 & 23.2 & 9.4 & 100 \\
\hline \multirow[t]{2}{*}{ East Asia (DEA) } & 1996 & 59.9 & 25.5 & 34.4 & 16.7 & 12.3 & 17.6 & 17.5 & 100 & 62.9 & 31.0 & 31.9 & 7.7 & 18.7 & 21.3 & 13.6 & 100 \\
\hline & 2003 & 66.9 & 22.8 & 44.1 & 20.1 & 16.2 & 13.6 & 14.3 & 100 & 70.7 & 24.9 & 45.8 & 13.6 & 24.4 & 15.7 & 10.9 & 100 \\
\hline \multirow[t]{3}{*}{ Greater China (GCH } & 1992 & 78.9 & 34.1 & 44.7 & 28.0 & 4.3 & 8.4 & 18.1 & 100 & 80.5 & 28.1 & 52.4 & 25.0 & 10.6 & 14.6 & 14.8 & 100 \\
\hline & 1996 & 71.7 & 25.2 & 46.5 & 25.1 & 6.4 & 10.8 & 25.0 & 100 & 83.0 & 31.7 & 51.3 & 15.1 & 14.7 & 14.7 & 13.7 & 100 \\
\hline & 2003 & 74.2 & 26.1 & 48.0 & 22.8 & 5.9 & 8.4 & 22.7 & 100 & 95.6 & 26.5 & 69.1 & 16.0 & 23.6 & 8.6 & 11.0 & 100 \\
\hline \multirow[t]{2}{*}{ AFTA } & 1992 & 52.7 & 29.0 & 23.7 & 4.8 & 14.4 & 18.5 & 17.6 & 100 & 60.4 & 31.2 & 29.2 & 3.9 & 21.0 & 20.4 & 12.5 & 100 \\
\hline & 1996 & 53.8 & 26.3 & 27.5 & 5.8 & 17.1 & 18.1 & 17.4 & 100 & 59.4 & 28.0 & 31.4 & 4.5 & 21.5 & 20.9 & 12.7 & 100 \\
\hline \multirow{2}{*}{ NAFTA } & 1996 & 33.7 & 14.9 & 18.8 & 8.0 & 7.8 & 38.5 & 16.7 & 100 & 38.4 & 19.4 & 19.0 & 2.9 & 10.4 & 39.5 & 13.1 & 100 \\
\hline & 2003 & 33.8 & 10.1 & 23.7 & 14.3 & 6.1 & 35.3 & 18.0 & 100 & 35.1 & 13.4 & 21.7 & 7.9 & 9.6 & 41.5 & 13.8 & 100 \\
\hline \multirow[t]{3}{*}{$\overline{E U}$} & 1992 & 11.8 & 6.3 & 5.5 & 2.6 & 2.0 & 8.6 & 66.8 & 100 & 11.2 & 7.3 & 3.9 & 0.7 & 2.5 & 11.9 & 67.4 & 100 \\
\hline & 1996 & 12.4 & 5.1 & 7.3 & 3.3 & 3.0 & 9.5 & 63.5 & 100 & 15.2 & 7.2 & 8.0 & 1.4 & 4.8 & 14.3 & 59.7 & 100 \\
\hline & 2003 & 14.7 & 4.1 & 10.6 & 6.2 & 3.0 & 9.0 & 52.8 & 100 & 16.7 & 5.3 & 11.4 & 4.2 & 5.5 & 11.2 & 52.8 & 100 \\
\hline \multirow[t]{3}{*}{ World } & 1992 & 24.8 & 12.0 & 12.8 & 6.5 & 4.2 & 17.4 & 44.9 & 100 & 27.1 & 15.4 & 11.7 & 3.0 & 6.5 & 23.6 & 40.3 & 100 \\
\hline & 1996 & 26.2 & 10.4 & 15.8 & 7.3 & 6.0 & 19.5 & 40.3 & 100 & 34.5 & 13.2 & 21.4 & 0.5 & 9.4 & 40.7 & 14.8 & 100 \\
\hline & 2003 & 29.4 & 8.5 & 20.9 & 11.5 & 6.2 & 17.3 & 34.3 & 100 & 36.8 & 12.1 & 24.7 & 8.2 & 12.0 & 19.5 & 27.8 & 100 \\
\hline
\end{tabular}




\begin{tabular}{|c|c|c|c|c|c|c|c|c|c|c|c|c|c|c|c|c|c|}
\hline & \multicolumn{9}{|c|}{ A3: Total manufacturing trade $(\mathrm{M}+\mathrm{X})$} & \multicolumn{8}{|c|}{ B3: Parts and components trade $(\mathrm{M}+\mathrm{X})$} \\
\hline Trade $(\mathrm{M}+\mathrm{X})$ & & EA & Japan & DEA & $\mathrm{GCH}$ & AFTA & NAFTA & EU & Total & EA & Japan & DEA & $\mathrm{GCH}$ & AFTA & NAFTA & EU & Total \\
\hline \multirow[t]{2}{*}{ East Asia (EA) } & 1992 & 44.1 & 11.2 & 32.8 & 18.0 & 10.9 & 26.4 & 19.5 & 100 & 50.9 & 14.5 & 36.4 & 11.8 & 19.7 & 30.3 & 14.8 & 100 \\
\hline & 1996 & 50.1 & 12.8 & 36.2 & 16.8 & 14.8 & 24.6 & 17.7 & 100 & 55.7 & 15.4 & 40.3 & 11.2 & 23.6 & 27.3 & 13.8 & 100 \\
\hline \multirow[t]{3}{*}{ Japan } & 1992 & 26.1 & 0.0 & 26.1 & 9.7 & 10.8 & 32.2 & 22.4 & 100 & 29.6 & 0.0 & 29.6 & 6.3 & 16.2 & 38.7 & 16.3 & 100 \\
\hline & 1996 & 35.2 & 0.0 & 35.2 & 12.9 & 15.9 & 30.2 & 18.3 & 100 & 39.1 & 0.0 & 39.1 & 9.0 & 22.3 & 35.2 & 12.7 & 100 \\
\hline & 2003 & 40.5 & 0.0 & 40.5 & 21.8 & 12.3 & 25.8 & 16.0 & 100 & 50.5 & 0.0 & 50.5 & 22.2 & 19.2 & 23.8 & 11.6 & 100 \\
\hline \multirow[t]{2}{*}{ East Asia (DEA) } & 1996 & 53.2 & 18.3 & 34.9 & 17.9 & 13.4 & 20.9 & 16.7 & 100 & 60.3 & 21.7 & 38.6 & 11.7 & 22.8 & 22.4 & 13.6 & 100 \\
\hline & 2003 & 55.6 & 15.5 & 40.1 & 21.9 & 13.3 & 19.4 & 15.0 & 100 & 69.5 & 17.3 & 52.2 & 23.7 & 22.5 & 15.0 & 11.1 & 100 \\
\hline \multirow[t]{3}{*}{ Greater China $(\mathrm{GCH})$} & 1992 & 71.3 & 23.6 & 47.8 & 33.8 & 5.1 & 12.0 & 17.0 & 100 & 33.9 & 15.8 & 18.0 & 4.8 & 7.1 & 24.5 & 41.0 & 100 \\
\hline & 1996 & 62.7 & 19.4 & 43.3 & 25.6 & 6.8 & 16.2 & 22.8 & 100 & 41.3 & 15.9 & 25.4 & 5.6 & 10.6 & 25.5 & 33.1 & 100 \\
\hline & 2003 & 57.9 & 18.1 & 39.8 & 21.0 & 6.3 & 17.3 & 21.8 & 100 & 50.4 & 12.7 & 37.7 & 13.5 & 13.0 & 20.5 & 28.3 & 100 \\
\hline \multirow[t]{2}{*}{ AFTA } & 1992 & 45.5 & 19.9 & 25.6 & 5.8 & 16.6 & 22.4 & 18.6 & 100 & 54.9 & 21.8 & 33.0 & 5.3 & 24.5 & 23.8 & 13.0 & 100 \\
\hline & 1996 & 49.7 & 19.1 & 30.6 & 6.9 & 20.1 & 20.6 & 16.7 & 100 & 56.0 & 19.7 & 36.3 & 5.9 & 26.5 & 21.6 & 13.4 & 100 \\
\hline \multirow{2}{*}{ NAFTA } & 1996 & 26.9 & 11.3 & 15.6 & 5.8 & 6.8 & 42.8 & 16.4 & 100 & 31.2 & 13.4 & 17.8 & 3.0 & 10.1 & 41.5 & 15.1 & 100 \\
\hline & 2003 & 26.2 & 7.8 & 18.4 & 10.1 & 5.4 & 43.3 & 16.6 & 100 & 29.3 & 9.0 & 20.3 & 6.6 & 9.8 & 45.0 & 13.8 & 100 \\
\hline \multirow[t]{3}{*}{$\mathrm{EU}$} & 1992 & 8.7 & 4.1 & 4.6 & 2.0 & 1.9 & 8.4 & 65.4 & 100 & 8.7 & 4.1 & 4.6 & 1.3 & 2.6 & 10.5 & 64.6 & 100 \\
\hline & 1996 & 10.0 & 3.6 & 6.4 & 2.7 & 2.8 & 8.9 & 61.3 & 100 & 12.3 & 4.3 & 7.9 & 1.8 & 4.6 & 12.2 & 57.7 & 100 \\
\hline & 2003 & 10.5 & 2.9 & 7.6 & 4.3 & 2.3 & 10.3 & 51.7 & 100 & 13.2 & 3.3 & 9.9 & 4.1 & 4.5 & 10.6 & 50.9 & 100 \\
\hline \multirow[t]{3}{*}{ World } & 1992 & 20.1 & 7.7 & 12.4 & 6.1 & 4.5 & 19.0 & 43.9 & 100 & 22.8 & 9.0 & 13.9 & 4.0 & 7.7 & 24.3 & 38.7 & 100 \\
\hline & 1996 & 22.7 & 7.4 & 15.4 & 6.7 & 6.3 & 20.4 & 39.0 & 100 & 28.9 & 8.9 & 20.0 & 1.0 & 9.6 & 44.4 & 14.3 & 100 \\
\hline & 2003 & 24.2 & 6.1 & 18.1 & 10.0 & 5.6 & 20.4 & 33.6 & 100 & 34.5 & 8.0 & 26.5 & 11.3 & 11.4 & 20.3 & 27.3 & 100 \\
\hline
\end{tabular}

Notes: (1) Including Japan (2) Including AFTA

Source: Complied from UN Comtrade Database using the commodity/country classification described in the text (Section 3). 
Table 5

Intra-Regional Trade Shares: Total Manufacturing, Parts and Components, and Final Trade (\%), 1992, 1993 and $2003^{1}$

\begin{tabular}{|c|c|c|c|c|c|c|c|c|c|c|c|c|}
\hline A: Total Manufacturing & & East Asia & $\begin{array}{r}\text { Developing } \\
\text { East Asia } \\
\end{array}$ & AFTA & $\begin{array}{r}\text { South } \\
\text { Asia }\end{array}$ & CER & NAFTA & EU & CEEC & EFTA & MERCOSUR & ANDEAN \\
\hline \multirow[t]{3}{*}{ Exports $(\mathrm{X})$} & 1992 & 36.6 & 35.6 & 19.5 & 2.8 & 24.6 & 44.6 & 64.1 & 1.4 & 1.4 & 21.4 & 25.4 \\
\hline & 1996 & 43.8 & 35.6 & 23.8 & 3.3 & 25.5 & 48.0 & 59.4 & 6.8 & 1.7 & 34.5 & 35.5 \\
\hline & 2003 & 45.6 & 37.6 & 21.7 & 3.0 & 25.3 & 55.2 & 50.8 & 6.9 & 1.5 & 18.4 & 26.6 \\
\hline \multirow[t]{3}{*}{ Imports (M) } & 1992 & 55.2 & 34.7 & 14.4 & 2.1 & 5.5 & 34.4 & 66.8 & 1.1 & 1.4 & 15.3 & 3.9 \\
\hline & 1996 & 55.7 & 34.7 & 17.3 & 2.8 & 6.0 & 38.5 & 63.5 & 4.3 & 1.4 & 15.2 & 9.3 \\
\hline & 2003 & 65.6 & 45.4 & 22.7 & 3.0 & 5.3 & 35.3 & 52.8 & 5.4 & 1.4 & 14.0 & 8.5 \\
\hline \multirow[t]{3}{*}{ Trade $(\mathrm{X}+\mathrm{M})$} & 1992 & 44.1 & 35.3 & 16.8 & 2.5 & 9.6 & 39.0 & 65.4 & 1.2 & 1.4 & 17.9 & 7.3 \\
\hline & 1996 & 50.1 & 36.2 & 21.5 & 3.1 & 10.5 & 42.8 & 61.3 & 5.3 & 1.5 & 21.1 & 14.8 \\
\hline & 2003 & 53.2 & 40.4 & 21.6 & 3.0 & 9.5 & 43.3 & 51.7 & 6.1 & 1.5 & 16.0 & 12.6 \\
\hline \multicolumn{13}{|l|}{ B: Parts and Components } \\
\hline \multirow[t]{3}{*}{ Exports $(\mathrm{X})$} & 1992 & 44.4 & 46.9 & 29.3 & 4.8 & 24.2 & 46.2 & 62.1 & 1.7 & 1.3 & 23.6 & 24.3 \\
\hline & 1996 & 52.3 & 46.8 & 32.7 & 4.6 & 22.5 & 43.5 & 55.9 & 5.5 & 1.5 & 36.8 & 24.4 \\
\hline & 2003 & 64.9 & 58.9 & 28.5 & 3.8 & 19.0 & 48.6 & 49.1 & 5.1 & 0.9 & 15.4 & 20.0 \\
\hline \multirow[t]{3}{*}{ Imports (M) } & 1992 & 59.3 & 31.4 & 21.0 & 0.9 & 4.4 & 42.7 & 67.4 & 1.0 & 1.2 & 14.7 & 1.5 \\
\hline & 1996 & 59.7 & 32.0 & 21.7 & 0.7 & 3.0 & 39.5 & 59.7 & 3.6 & 1.1 & 12.4 & 2.5 \\
\hline & 2003 & 69.7 & 45.9 & 24.9 & 1.2 & 3.5 & 41.5 & 52.8 & 3.8 & 1.0 & 6.6 & 3.6 \\
\hline \multirow{3}{*}{ Trade $(\mathrm{X}+\mathrm{M})$} & 1992 & 50.9 & 38.1 & 24.6 & 1.6 & 18.9 & 44.5 & 64.6 & 1.3 & 1.2 & 17.9 & 3.1 \\
\hline & 1996 & 55.7 & 38.8 & 26.7 & 1.5 & 9.2 & 41.5 & 57.7 & 4.4 & 1.3 & 18.7 & 4.6 \\
\hline & 2003 & 67.3 & 52.5 & 27.0 & 1.9 & 7.9 & 45.0 & 50.9 & 4.4 & 1.0 & 9.3 & 6.2 \\
\hline \multicolumn{13}{|l|}{ C: Final goods } \\
\hline \multirow[t]{3}{*}{ Exports(X) } & 1992 & 35.0 & 33.7 & 16.3 & 2.7 & 24.2 & 44.1 & 64.4 & 1.4 & 1.4 & 21.0 & 25.5 \\
\hline & 1996 & 41.2 & 32.5 & 19.3 & 3.2 & 26.3 & 49.6 & 60.0 & 6.9 & 1.7 & 34.2 & 35.9 \\
\hline & 2003 & 38.8 & 30.1 & 17.0 & 3.0 & 26.5 & 57.3 & 51.1 & 7.3 & 1.5 & 18.8 & 26.9 \\
\hline \multirow[t]{3}{*}{ Imports (M) } & 1992 & 54.3 & 35.7 & 11.9 & 2.3 & 5.4 & 32.6 & 66.7 & 1.1 & 1.5 & 15.5 & 4.2 \\
\hline & 1996 & 54.1 & 35.4 & 14.5 & 3.1 & 6.5 & 38.2 & 64.3 & 4.4 & 1.5 & 15.7 & 9.9 \\
\hline & 2003 & 61.9 & 43.3 & 18.7 & 3.3 & 5.5 & 34.1 & 52.8 & 5.8 & 1.5 & 15.9 & 8.9 \\
\hline \multirow[t]{3}{*}{ Trade $(\mathrm{X}+\mathrm{M})$} & 1992 & 52.5 & 44.6 & 23.9 & 2.5 & 9.4 & 37.6 & 65.5 & 1.2 & 1.4 & 17.9 & 7.8 \\
\hline & 1996 & 46.8 & 33.9 & 16.8 & 3.2 & 10.8 & 43.2 & 62.0 & 5.5 & 1.6 & 21.6 & 15.7 \\
\hline & 2003 & 47.6 & 35.2 & 17.7 & 3.1 & 9.7 & 42.9 & 51.9 & 6.5 & 1.5 & 17.3 & 13.2 \\
\hline
\end{tabular}

Note 1 For the country coverage of the regions/RTAs covered in this table, see Appendix A-1 
Table 6

Regression Estimates of the Determinants of Bilateral Trade Flows ${ }^{1}$

\begin{tabular}{|c|c|c|c|c|c|c|c|c|}
\hline & \multicolumn{4}{|c|}{ Parts and components } & \multicolumn{4}{|l|}{ Final goods } \\
\hline & \multicolumn{2}{|c|}{$\begin{array}{l}\text { Equation } 1 \\
\text { Log of imports }\end{array}$} & \multicolumn{2}{|c|}{$\begin{array}{l}\text { Equation } 2 \\
\text { Log of exports }\end{array}$} & \multicolumn{2}{|c|}{$\begin{array}{l}\text { Equation } 3 \\
\text { Log of import }\end{array}$} & \multicolumn{2}{|c|}{$\begin{array}{l}\text { Equation } 4 \\
\text { Log of exports }\end{array}$} \\
\hline Explanatory variables & Coefficient & S.E. & Coefficient & S.E. & Coefficient & S.E. & Coefficient & S.E. \\
\hline Log GDP, reporter & 0.78 & {$[0.02]^{* * *}$} & 1.25 & {$[0.01]^{* * *}$} & 0.72 & {$[0.01]^{* * *}$} & 1.16 & {$[0.01]^{* * *}$} \\
\hline Log GDP, partner & 1.40 & {$[0.01]^{* * *}$} & 0.88 & {$[0.01]^{* * *}$} & 1.37 & {$[0.01]^{* * *}$} & 0.76 & {$[0.01]^{* * *}$} \\
\hline Log per capital (PGDP), reporter & 0.11 & {$[0.03]^{* * *}$} & 0.66 & {$[0.02]^{* * *}$} & -0.01 & {$[0.02]$} & 0.56 & {$[0.02]^{* * *}$} \\
\hline Log per capita GDP, partner & 0.44 & {$[0.02]^{* * *}$} & 0.06 & {$[0.01]^{* * *}$} & 0.38 & {$[0.01]^{* * *}$} & -0.00 & {$[0.01]$} \\
\hline Log absolute PGDP difference & -0.06 & {$[0.01]^{* * *}$} & -0.06 & {$[0.01]^{* * *}$} & -0.05 & {$[0.01]^{* * *}$} & -0.08 & {$[0.01]^{* * *}$} \\
\hline Log relative labour cost & 0.29 & {$[0.05]^{* * *}$} & -0.16 & {$[0.04]^{* * *}$} & 0.26 & {$[0.06]^{* * *}$} & -0.22 & {$[0.04]^{* * *}$} \\
\hline Log distance & -1.19 & {$[0.04]^{* * *}$} & -1.46 & {$[0.03]^{* * *}$} & -1.06 & {$[0.04]^{* * *}$} & -1.21 & {$[0.03]^{* * *}$} \\
\hline Common language dummy & 0.58 & {$[0.06]^{* * *}$} & 1.08 & {$[0.05]^{* * *}$} & 0.36 & {$[0.05]^{* * *}$} & 0.94 & {$[0.04]^{* * *}$} \\
\hline Common land border dummy & -0.09 & {$[0.07]$} & 0.14 & {$[0.08]^{*}$} & -0.01 & {$[0.07]$} & 0.36 & {$[0.08]^{* * *}$} \\
\hline \multicolumn{9}{|l|}{ Regional/country dummies } \\
\hline AFTA insiders & 2.58 & {$[0.17]^{* * *}$} & 2.39 & {$[0.16]^{* * *}$} & 1.63 & {$[0.13]^{* * *}$} & 0.90 & {$[0.12]^{* * *}$} \\
\hline AFTA outsiders & 0.89 & {$[0.09]^{* * *}$} & 0.79 & {$[0.08]^{* * *}$} & 0.56 & {$[0.08]^{* * *}$} & -0.13 & {$[0.07]^{*}$} \\
\hline EU insiders & -1.11 & {$[0.13]^{* * *}$} & -1.00 & {$[0.10]^{* * *}$} & -1.25 & {$[0.13]^{* * *}$} & -0.17 & {$[0.10]^{* *}$} \\
\hline EU outsiders & -0.29 & {$[0.09]^{* * *}$} & 0.58 & {$[0.06]^{* * *}$} & -0.84 & {$[0.09]^{* * *}$} & 0.69 & {$[0.07]^{* * *}$} \\
\hline NAFTA insiders & 0.24 & {$[0.14]^{*}$} & 0.21 & {$[0.08]^{* *}$} & -0.57 & {$[0.14]^{* * *}$} & -0.14 & {$[0.09]$} \\
\hline NAFTA outsiders & 0.35 & {$[0.13]^{*}$} & 0.34 & {$[0.09]^{* * *}$} & -0.25 & {$[0.10]^{* *}$} & 0.01 & {$[0.08]$} \\
\hline MERCOSUR insiders & -068 & {$[0.21]^{* *}$} & -0.52 & {$[0.22]^{* *}$} & -0.26 & {$[0.17]$} & 0.14 & {$[0.19]$} \\
\hline MERCOSUR_outsiders & -0.64 & {$[0.10]^{* * *}$} & -0.88 & {$[0.09]^{* * *}$} & -0.78 & {$[0.10]^{* * *}$} & -1.19 & {$[0.09]^{* * *}$} \\
\hline ANDEAN insiders & -0.71 & {$[0.14]^{* * *}$} & -0.05 & {$[0.15]$} & -0.74 & {$[0.14]^{* * *}$} & 0.11 & {$[0.17]$} \\
\hline ANDEAN outsider & -1.13 & {$[0.11]^{* * *}$} & -2.49 & {$[0.10]^{* * *}$} & -1.08 & {$[0.11]^{* * *}$} & -2.41 & {$[0.10]^{* * *}$} \\
\hline Singapore & 1.20 & {$[0.13]^{* * *}$} & 0.84 & {$[0.12]^{* * *}$} & 0.99 & {$[0.12]^{* * *}$} & 0.68 & {$[0.10]^{* * *}$} \\
\hline Ireland & 0.35 & {$[0.15]^{* *}$} & 1.37 & {$[0.10]^{* * *}$} & -0.13 & {$[0.12]$} & -0.18 & {$[0.08]^{* *}$} \\
\hline East Asia insiders & 0.50 & {$[0.15]^{* * *}$} & 1.45 & {$[0.10]^{* * *}$} & -0.43 & {$[0.14]^{* * *}$} & 1.53 & {$[0.09]^{* * *}$} \\
\hline East Asia outsider & -0.55 & {$[0.11]^{* * *}$} & 1.90 & {$[0.74]^{* * *}$} & -1.02 & {$[0.11]^{* * *}$} & 2.56 & {$[0.07]^{* * *}$} \\
\hline Constant & -35.08 & {$[0.82]^{* * *}$} & -33.70 & {$[0.66]^{* * *}$} & -31.28 & {$[0.76]^{* * *}$} & -28.40 & {$[0.60]^{* * *}$} \\
\hline N. of Observations & 11580 & & 11160 & & 11546 & & 11296 & \\
\hline
\end{tabular}




\begin{tabular}{|c|c|c|c|c|}
\hline $\mathrm{R}^{2}$ & 0.70 & 0.78 & 0.69 & 0.79 \\
\hline F & 1036.89 & 1172.15 & 836.97 & 1091.63 \\
\hline RMSE & 1.94 & 1.59 & 1.82 & 1.45 \\
\hline & & & & \\
\hline
\end{tabular}

Note

1 The standard errors (SEs) of the regression coefficients have been derived using the Huber-While consistent variance-covariance ('sandwich') estimator. Statistical significant (based on the standard t-test) is denoted as $* * * 1 \%$, $* * 5 \%$, and $* 10 \%$. 
Figure 1: World Trade in Parts and Components (P\&Cs)*

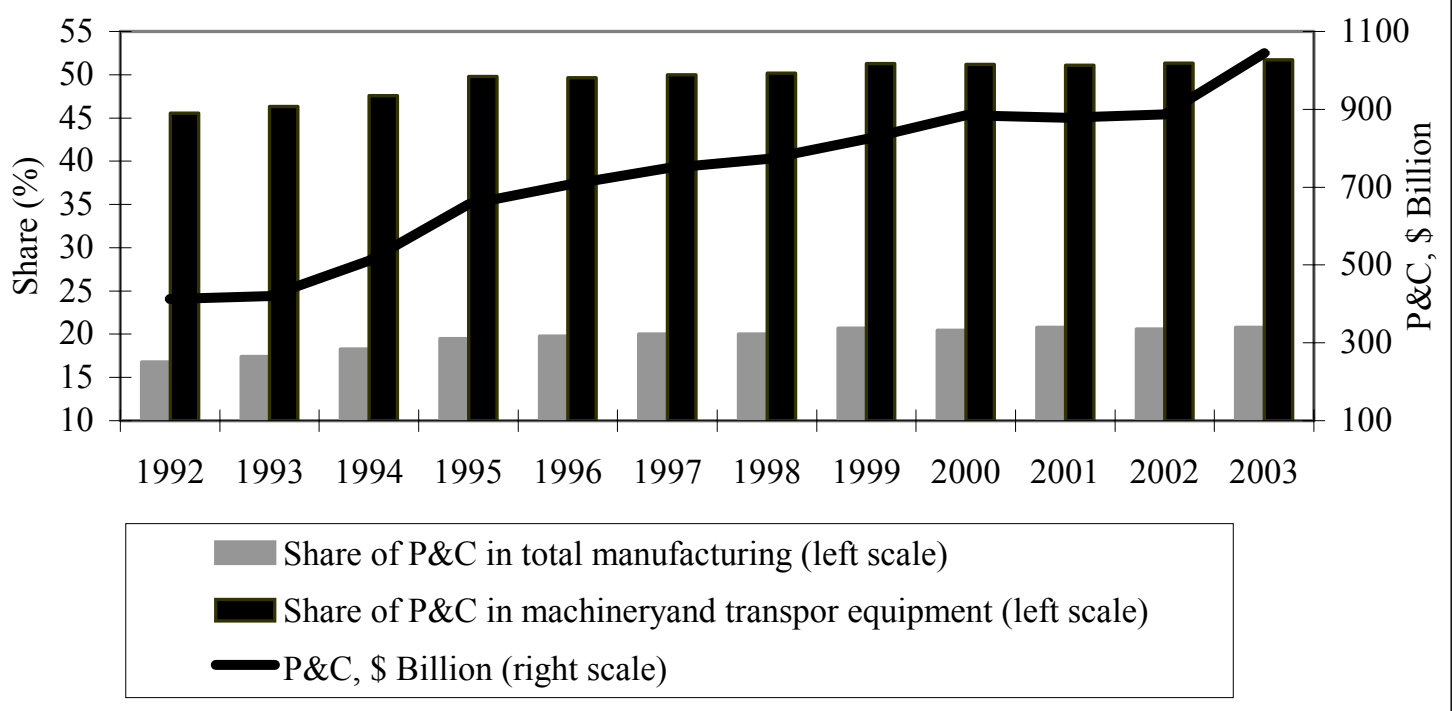

Figure 2: Parts and Components Exports (US\$ billion)

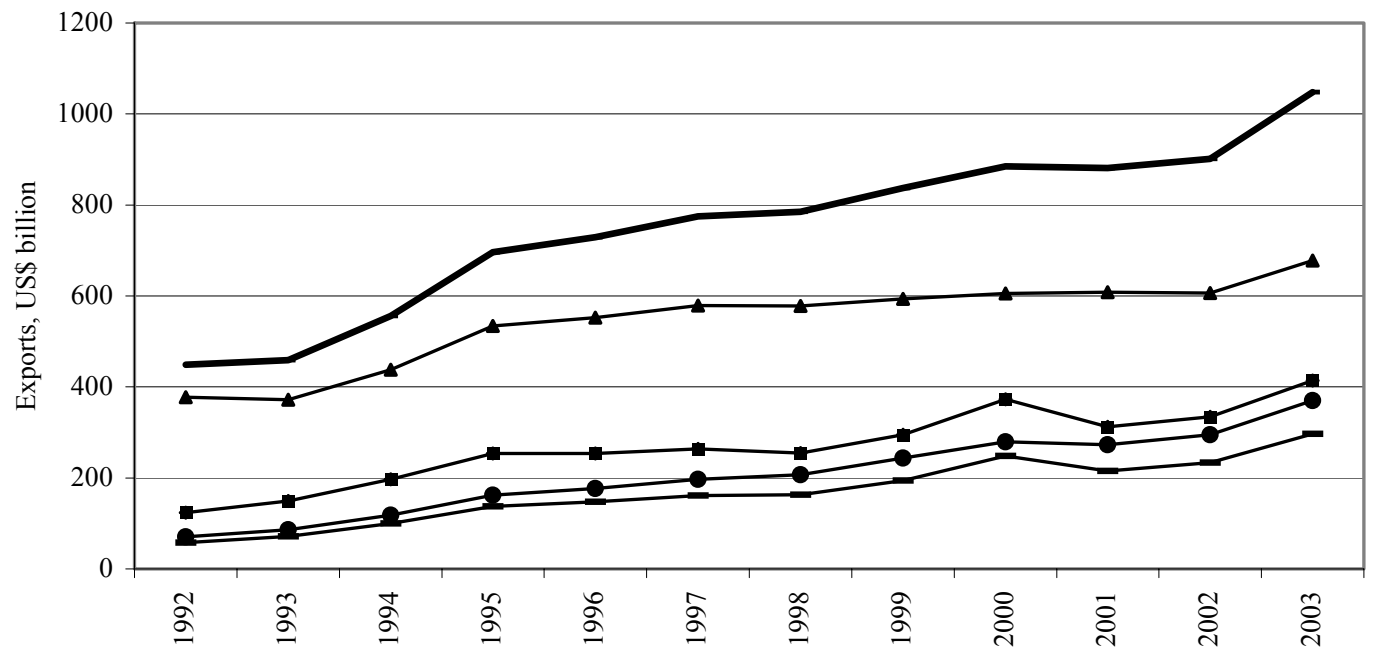

$\rightarrow$ East Asia $\quad \longrightarrow$ Developing East Asia $\rightarrow$ Developed countries

$\rightarrow$ Developing countries $\longrightarrow$ World 
Appendix Table A-1

Definition of Variables and Data Source

\begin{tabular}{|c|c|c|}
\hline Label & Definition & Data Source \\
\hline$X M$ & $\begin{array}{l}\text { Bilateral trade flows } \\
\text { ('Component' and 'Final Goods' } \\
\text { trade) at constant (1995) dollar }\end{array}$ & $\begin{array}{l}\text { Trade flows: UN-COMTRADE, online } \\
\text { database } \\
\text { Exchange rates: IMF, International Financial Statistics (line rf) }\end{array}$ \\
\hline GDP & Real GDP (at 1995 price) & World Development Indicator, The World Bank \\
\hline DIST & $\begin{array}{l}\text { the Great Circle distance between } \\
\text { capital cities of two countries }\end{array}$ & $\begin{array}{l}\text { Joe Haveman's International Trade Data, at } \\
<\text { http://www.macalester.edu/research/economics/PAGE/HAVEMAN/ } \\
\text { Trade.Resources/TradeData.html }>\end{array}$ \\
\hline$R W G$ & $\begin{array}{l}\text { Relative labour cost in the } \\
\text { manufacturing, adjusted for } \\
\text { exchange rate changes: } \\
R W G_{i j}=\frac{W_{i}}{W_{j}} E_{i j} \\
\text { where, } \\
\mathrm{W}=\text { manufacturing wage index } \\
(1992=100) \\
E=\text { nominal bilateral exchange } \\
\text { rate expressed as the value of } i \text { 's } \\
\text { currency in terms of } j \text { 's currency. } \\
\text { By construct, an increase } \\
\text { (decrease) in } R^{2} G_{i j} \text { indicates a } \\
\text { deterioration (improvement) in } \\
i \text { 's cost competitiveness vis a vis } \\
j\end{array}$ & $\begin{array}{l}\text { Annual manufacturing wages data for USA: 'Interactive database of } \\
\text { National Income and Product Accounts Tables' at } \\
<\text { http://www.bea.gov/bea/dn/nipaweb/SelectTable.asp?Selected=N\#S6> } \\
\text { under Section } 6 \text { - Income and Employment by Industry } \\
\text { All other countries: US Bureau of Economic Analysis (BEA) online database, } \\
\text { 'Survey of U.S. Direct Investment Abroad' } \\
<\underline{\text { http://www.bea.doc.gov/bea/uguide.htm\#_1_23>. }} \\
\text { Bilateral exchange rates: derived from bilateral US\$ exchange rates obtained } \\
\text { from IMF, International Financial Statistic. }\end{array}$ \\
\hline
\end{tabular}




\section{Appendix Table A2}

Country groups/Regional Trading Arrangements (RTAs) Covered in the Study ${ }^{1}$

\begin{tabular}{|c|c|c|c|c|c|c|c|c|}
\hline AFTA & East Asia & CER & EU & EFTA* & CEEC* & NAFTA & MERCOSUR & ANDEAN \\
\hline & AFTA & Australia & Austria & Iceland $^{*}$ & Bulgaria* & USA & Argentina & Bolivia \\
\hline Indonesia & Japan & New Zealand & Belgium & Norway* & Croatia* & Canada & Brazil & Colombia \\
\hline Philippines & Korea, Rep. of & & Denmark & Switzerland* & Czech Rep* & Mexico & Paraguay & Ecuador \\
\hline Malaysia & China & & Finland & & Hungary* & & Uruguay & Peru* \\
\hline Singapore & Hong Kong, China & & France & & Poland * & & & Venezuela \\
\hline Thailand & Taiwan* & & Germany & & Rumania* & & & \\
\hline \multirow[t]{8}{*}{ Vietnam $^{*}$} & & & Ireland & & Russia* & & & \\
\hline & & & Italy & & Slovak Rep* & & & \\
\hline & & & Netherlands & & & & & \\
\hline & & & Greece & & & & & \\
\hline & & & Portugal & & & & & \\
\hline & & & Spain & & & & & \\
\hline & & & Sweden & & & & & \\
\hline & & & UK & & & & & \\
\hline
\end{tabular}

Notes:

1 All country groups listed below except East Asia and CEEC are under RTAs. Countries marked with asterisks $(*)$ are not covered in the gravity model estimation.

Legend :

AFTA ASEAN Free Trade Area; EFTA European Free Trade Area; ANDEAN Andean Pact;

EU European Union; CER Closer Economic Relations agreement; MERCOSUR The Common Market of the South;

CEEC Central and Eastern European Countries; NAFTA North American Free Trade Agree. 
